\title{
Highly Selective Hydroboration of Terminal Alkenes Catalyzed by a Cobalt Pincer Complex Featuring a Central Reactive N- Heterocyclic Phosphido Fragment.
}

\author{
Andrew M. Poitras, Leah K. Oliemuller, Gillian P. Hatzis, Christine M. Thomas*
}

Department of Chemistry and Biochemistry, The Ohio State University, 100 West 18th Avenue, Columbus, Ohio 43210, United States

Table of Contents

\begin{tabular}{|c|c|}
\hline & Pages \\
\hline Alkene Hydrogenation Procedure using (PPP)Co(PMes) (C). & S4 \\
\hline $\begin{array}{l}\text { Table S1. Screening styrene hydrogenation using (PPP)Co(PMe } 3)(\mathbf{C}) \text { as a } \\
\text { catalyst. }\end{array}$ & S4 \\
\hline $\begin{array}{l}\text { Styrene hydroboration in the presence of TMEDA to test for catalysis by } \mathrm{BH}_{3} \\
\text { or HBPin decomposition products. }\end{array}$ & S4 \\
\hline Characterization Data for Hydroboration Products 2a-2l'. & S5-S10 \\
\hline${ }^{1} \mathrm{H},{ }^{13} \mathrm{C},{ }^{19} \mathrm{~F}$, and ${ }^{11} \mathrm{~B}$ NMR Data for Hydroboration Products 2a-2l'. & $\begin{array}{l}\text { S11- } \\
\text { S26 }\end{array}$ \\
\hline $\begin{array}{l}\text { Figure S1. }{ }^{1} \mathrm{H} \text { NMR spectrum of } 4,4,5,5 \text {-tetramethyl-2-phenylethyl-1,3,2- } \\
\text { dioxaborolane (2a). }\end{array}$ & S11 \\
\hline $\begin{array}{l}\text { Figure S2. }{ }^{13} \mathrm{C}\left\{{ }^{1} \mathrm{H}\right\} \text { NMR spectrum of } 4,4,5,5 \text {-tetramethyl-2-phenylethyl- } \\
\text { 1,3,2-dioxaborolane }(\mathbf{2 a}) \text {. }\end{array}$ & S11 \\
\hline $\begin{array}{l}\text { Figure S3. }{ }^{11} \mathrm{~B} \text { NMR spectrum of } 4,4,5,5 \text {-tetramethyl-2-phenylethyl-1,3,2- } \\
\text { dioxaborolane }(\mathbf{2 a}) \text {. }\end{array}$ & S12 \\
\hline $\begin{array}{l}\text { Figure S4. }{ }^{1} \mathrm{H} \text { NMR spectrum of 4,4,5,5-tetramethyl-2-(4-methylphenethyl)- } \\
\text { 1,3,2-dioxaborolane (2b). }\end{array}$ & S12 \\
\hline $\begin{array}{l}\text { Figure S5. }{ }^{13} \mathrm{C}\left\{{ }^{1} \mathrm{H}\right\} \quad \mathrm{NMR} \quad \text { spectrum of } \\
\text { methylphenethyl)-1,3,2-dioxaborolane }(\mathbf{2 b}) .\end{array}$ & S13 \\
\hline $\begin{array}{l}\text { Figure S6. }{ }^{11} \text { B NMR spectrum of 4,4,5,5-tetramethyl-2-(4-methylphenethyl)- } \\
\text { 1,3,2-dioxaborolane }(\mathbf{2 b}) \text {. }\end{array}$ & S13 \\
\hline $\begin{array}{l}\text { Figure S7. }{ }^{1} \mathrm{H} \quad \mathrm{NMR} \text { spectrum of } 2 \text {-(4-methoxyphenethyl)-4,4,5,5- } \\
\text { tetramethyl-1,3,2-dioxaborolane (2c). }\end{array}$ & S14 \\
\hline $\begin{array}{l}\text { Figure S8. }{ }^{13} \mathrm{C}\left\{{ }^{1} \mathrm{H}\right\} \text { NMR spectrum of 2-(4-methoxyphenethyl)-4,4,5,5- } \\
\text { tetramethyl-1,3,2-dioxaborolane (2c). }\end{array}$ & S14 \\
\hline $\begin{array}{l}\text { Figure S9. }{ }^{11} \mathrm{~B} \text { NMR spectrum of 2-(4-methoxyphenethyl)-4,4,5,5- } \\
\text { tetramethyl-1,3,2-dioxaborolane (2c). }\end{array}$ & S15 \\
\hline $\begin{array}{l}\text { Figure S10. }{ }^{1} \mathrm{H} \text { NMR spectrum of 2-(4-fluorophenethyl)-4,4,5,5-tetramethyl- } \\
\text { 1,3,2-dioxaborolane (2d). }\end{array}$ & S15 \\
\hline
\end{tabular}




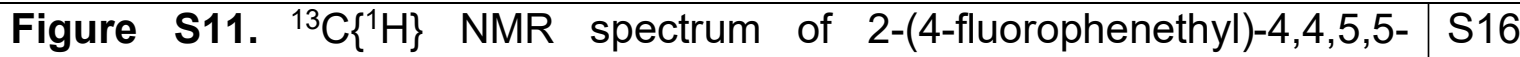
tetramethyl-1,3,2-dioxaborolane (2d).

Figure S12. ${ }^{19} \mathrm{~F}$ NMR spectrum of 2-(4-fluorophenethyl)-4,4,5,5-tetramethyl- S16 1,3,2-dioxaborolane (2d).

Figure S13. ${ }^{11} \mathrm{~B}$ NMR spectrum of 2-(4-fluorophenethyl)-4,4,5,5-tetramethyl- $\mathrm{S} 17$ 1,3,2-dioxaborolane (2d).

Figure S14. ${ }^{1} \mathrm{H}$ NMR spectrum of crude catalytic reaction mixture to form 2- $\mathrm{S} 17$ (4-chlorophenethyl)-4,4,5,5-tetramethyl-1,3,2-dioxaborolane (2e).

Figure S15. ${ }^{1} \mathrm{H}$ NMR spectrum of crude catalytic reaction mixture to form 2- $\mathrm{S} 18$ (4-bromophenethyl)-4,4,5,5-tetramethyl-1,3,2-dioxaborolane (2f).

Figure S16. ${ }^{1} \mathrm{H}$ NMR spectrum of 2-(cyclohexylmethyl)-4,4,5,5-tetramethyl- $\mathrm{S} 18$

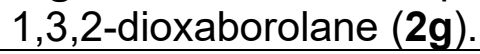

\begin{tabular}{llllll}
\hline Figure S17. ${ }^{13} \mathrm{C}\left\{{ }^{1} \mathrm{H}\right\}$ & NMR spectrum of 2-(cyclohexylmethyl)-4,4,5,5- & $\mathrm{S} 19$
\end{tabular} tetramethyl-1,3,2-dioxaborolane (2g).

Figure S18. ${ }^{11} \mathrm{~B}$ NMR spectrum of 2-(cyclohexylmethyl)-4,4,5,5-tetramethyl- $\mathrm{S} 19$ 1,3,2-dioxaborolane $\mathbf{( 2 g}$ ).

Figure S19. ${ }^{1} \mathrm{H}$ NMR spectrum of 2-hex-1-yl-4,4,5,5-tetramethyl-1,3,2- $\mathrm{S} 20$ dioxaborolane (2h).

Figure S20. ${ }^{13} \mathrm{C}\left\{{ }^{1} \mathrm{H}\right\}$ NMR spectrum of 2-hex-1-yl-4,4,5,5-tetramethyl-1,3,2- $\mathrm{S} 20$ dioxaborolane (2h).

Figure S21. ${ }^{11} \mathrm{~B}$ NMR spectrum of 2-hex-1-yl-4,4,5,5-tetramethyl-1,3,2- $\mathrm{S} 21$ dioxaborolane (2h).

Figure S22. ${ }^{1} \mathrm{H}$ NMR spectrum of 4,4,5,5-tetramethyl-2-(3-phenylpropyl)1,3,2-dioxaborolane (2i).

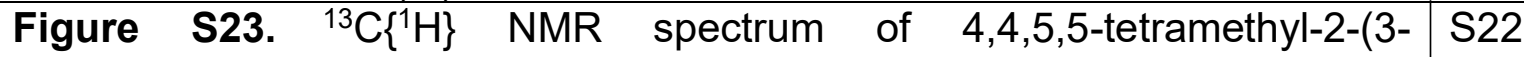
phenylpropyl)-1,3,2-dioxaborolane (2i).

Figure S24. ${ }^{11} \mathrm{~B}$ NMR spectrum of 4,4,5,5-tetramethyl-2-(3-phenylpropyl)- $\mathrm{S} 22$ 1,3,2-dioxaborolane (2i).

Figure S25. ${ }^{1} \mathrm{H}$ NMR spectrum of 2-(3,3-dimethylbutyl)-4,4,5,5-tetramethyl1,3,2-dioxaborolane (2j).

$\begin{array}{llllll}\text { Figure S26. }{ }^{13} \mathrm{C}\left\{{ }^{1} \mathrm{H}\right\} & \mathrm{NMR} & \text { spectrum of } 2-(3,3-\text { dimethylbutyl)-4,4,5,5- } & \mathrm{S} 23\end{array}$ tetramethyl-1,3,2-dioxaborolane (2j).

Figure S27. ${ }^{11} \mathrm{~B}$ NMR spectrum of 2-(3,3-dimethylbutyl)-4,4,5,5-tetramethyl1,3,2-dioxaborolane (2j).

Figure S28. ${ }^{1} \mathrm{H}$ NMR spectrum of crude catalytic reaction mixture to form 4,4,5,5-tetramethyl-2-(3-phenoxypropyl)-1,3,2-dioxaborolane (2k).

Figure S29. ${ }^{1} \mathrm{H}$ NMR spectrum of 2-(hex-5-en-2-yloxy)pinacolborane (2I) generated under standard catalytic conditions using a 1:1 ratio of HBPin to 5-hexen-2-one.

Figure S30. ${ }^{1} \mathrm{H}$ NMR spectrum of the mixture of $\mathbf{2 l}$ and 2l' generated under standard catalytic conditions using a 2:1 ratio of HBPin to 5-hexen-2-one $\left(400 \mathrm{~Hz}, \mathrm{CDCl}_{3}\right)$.

Figure S31. ${ }^{1} \mathrm{H}$ NMR spectrum of 2l' $\left(400 \mathrm{~Hz}, \mathrm{CDCl}_{3}\right)$.

Figure S32. ${ }^{31} \mathrm{P}\left\{{ }^{1} \mathrm{H}\right\}$ NMR spectra of the reaction mixture upon completion of catalysis and an authentic sample of $[(P P P) C o H]_{2}$. 
Figure S33. ${ }^{31} \mathrm{P}\left\{{ }^{1} \mathrm{H}\right\}$ NMR spectrum obtained upon addition of $\mathrm{PMe}_{3}$ to the $\mathrm{S} 27$ catalytic reaction mixture in the middle of catalysis and ${ }^{31} \mathrm{P}\left\{{ }^{1} \mathrm{H}\right\} N M R$ spectrum an authentic sample of $\left(\mathrm{PP}^{\mathrm{H}} \mathrm{P}\right) \mathrm{Co}(\mathrm{H}) \mathrm{PMe}_{3}$.

Figure S34. ${ }^{11} \mathrm{~B}$ NMR spectrum obtained upon addition of $20 \mathrm{~mol} \%$ TMEDA to the catalytic reaction mixture to verify that no $\mathrm{BH}_{3} \cdot \mathrm{TMEDA}$ or $\left(\mathrm{BH}_{3}\right)_{2} \cdot$ TMEDA had formed under the reaction conditions.

Figure S35. ${ }^{2} \mathrm{H}$ NMR spectrum of the product obtained upon styrene hydroboration with DBPin catalyzed by 1 in the presence of $\mathrm{KBEt}_{3} \mathrm{H}$.

References.

S27

S28

S29 


\section{Alkene Hydrogenation Procedure using (PPP)Co(PMeз) (C).}

(PPP)Co(PMe $)^{1}$ (C) $(0.0115 \mathrm{mg}, 0.015 \mathrm{mmol})$ was dissolved in $0.5 \mathrm{~mL}$ of $\mathrm{C}_{6} \mathrm{D}_{6}$ and added to a J-Young Tube. Styrene $(18 \mu \mathrm{L}, 0.15 \mathrm{mmol})$ was added to the J-Young Tube. The solution was degassed via three freeze-pump-thaw cycles. The headspace was refilled with $\mathrm{H}_{2}$ and the mixture was allowed to react for 42 hours at room temperature. Reaction progress was monitored by ${ }^{1} \mathrm{H}$ NMR spectroscopy through comparison of the integration of product to starting material ( $10 \%$ yield, see Table S1).

(PPP)Co(PMe $)^{1}$ (C) $(0.0128 \mathrm{mg}, 0.017 \mathrm{mmol})$ was dissolved in $0.5 \mathrm{~mL}$ of $\mathrm{C}_{6} \mathrm{D}_{6}$ and added to a J-Young Tube. Styrene $(20 \mu \mathrm{L}, 0.17 \mathrm{mmol})$ was added to the J-Young Tube. The solution was degassed via three freeze-pump-thaw cycles. The headspace was refilled with $\mathrm{H}_{2}$ and the mixture was allowed to react for 24-48 hours at $60^{\circ}$. Reaction progress was monitored by ${ }^{1} \mathrm{H}$ NMR spectroscopy through comparison of the integration of product to starting material ( $24 \mathrm{~h}: 15 \%$ yield; $48 \mathrm{~h}$ : $19 \%$ yield, see Table S1).

Table S1. Screening styrene hydrogenation using $(\mathrm{PPP}) \mathrm{Co}\left(\mathrm{PMe}_{3}\right)^{1}(\mathrm{C})$ as a catalyst. ${ }^{a}$

\begin{tabular}{|c|c|c|}
\hline Temperature & Time & Yield $^{\mathbf{b}}$ \\
\hline $25^{\circ} \mathrm{C}$ & $42 \mathrm{~h}$ & $10 \%$ \\
\hline $60^{\circ} \mathrm{C}$ & $24 \mathrm{~h}$ & $15 \%$ \\
\hline $60^{\circ} \mathrm{C}$ & $48 \mathrm{~h}$ & $19 \%$ \\
\hline
\end{tabular}

a Conditions: $10 \mathrm{~mol} \% \mathrm{C}, 1$ atm $\mathrm{H}_{2}, \mathrm{C}_{6} \mathrm{D}_{6}$ solvent. ${ }^{\mathrm{b}}$ Determined by comparing the relative integration of styrene and ethylbenzene using ${ }^{1} \mathrm{H}$ NMR spectroscopy.

\section{Styrene hydroboration in the presence of TMEDA to test for catalysis by $\mathrm{BH}_{3}$ or HBPin decomposition products.}

To a $20 \mathrm{~mL}$ vial equipped with a stir bar, (PPClP)CoCl $2(1)(0.010 \mathrm{~g}, 0.013 \mathrm{mmol}, 1.0 \mathrm{~mol}$ $\%)$, THF (3 mL), HBPin $(187.2 \mu \mathrm{L}, 1.29 \mathrm{mmol})$, styrene $(148.3 \mu \mathrm{L}, 1.29 \mathrm{mmol})$, and TMEDA $(38.6 \mu \mathrm{L}, 0.26 \mathrm{mmol})$ were added and stirred for $1 \mathrm{~min}$. KBEt $3 \mathrm{H}(27.1 \mu \mathrm{L}, 1.0 \mathrm{M}$ solution in THF, mmol) was added to the stirring solution via a glass syringe and the reaction was stirred at room temperature for $30 \mathrm{~min} .{ }^{11} \mathrm{~B}$ NMR spectroscopy was used to verify that no $\mathrm{BH}_{3} \cdot$ TMEDA (26.3 ppm) or $\left(\mathrm{BH}_{3}\right)_{2} \cdot$ TMEDA $(28.4 \mathrm{ppm})$ had formed under the reaction conditions (Figure S30). ${ }^{2}$ Upon completion, the solvent was removed in vacuo. Hexamethylbenzene $\left(162.2 \mu \mathrm{L}, 1.0 \mathrm{M}\right.$ in $\mathrm{CDCl}_{3}, 0.180 \mathrm{mmol}$ ) was added to the remaining oily residue via a glass syringe, and the resulting solution was diluted further with $\mathrm{CDCl}_{3} .{ }^{1} \mathrm{H}$ NMR spectroscopy was used to determine the yield by integration of the methyl BPin resonance at $1.22 \mathrm{ppm}$ relative to the resonance of the internal standard (hexamethylbenzene, $2.23 \mathrm{ppm})\left({ }^{1} \mathrm{H}\right.$ NMR yield: 96\%). 


\section{Characterization Data for 2a-2l'.}

\section{4,4,5,5-Tetramethyl-2-phenylethyl-1,3,2-dioxaborolane (2a).}

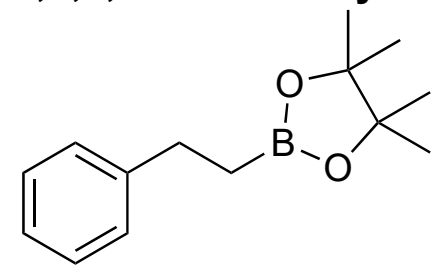

To a $20 \mathrm{~mL}$ vial equipped with a stir bar, (PPClP) $\mathrm{CoCl}_{2}$ (1) $(0.014$ g, $0.018 \mathrm{mmol}, 1.0 \mathrm{~mol} \%)$, THF (3 mL), HBPin $(262.1 \mu \mathrm{L}, 1.81$ $\mathrm{mmol})$, and styrene $(207.6 \mu \mathrm{L}, 1.81 \mathrm{mmol})$ were added and stirred for $1 \mathrm{~min}$. KBEt $3 \mathrm{H}(37.9 \mu \mathrm{L}, 1.0 \mathrm{M}$ solution in THF, 0.038 $\mathrm{mmol}$ ) was added to the stirring solution via a glass syringe and the reaction was stirred at room temperature for $30 \mathrm{~min}$. Upon completion, the solvent was removed in vacuo. Hexamethylbenzene $(180.6 \mu \mathrm{L}, 1.0 \mathrm{M}$ in $\mathrm{CDCl}_{3}, 0.180 \mathrm{mmol}$ ) was added to the remaining oily residue via a glass syringe, and the resulting solution was diluted further with $\mathrm{CDCl}_{3} .{ }^{1} \mathrm{H}$ NMR spectroscopy was used to determine the yield by integration of the methyl BPin resonance at $1.22 \mathrm{ppm}$ relative to the resonance of the internal standard (hexamethylbenzene, $2.23 \mathrm{ppm})\left({ }^{1} \mathrm{H}\right.$ NMR yield: $98 \%)$. The isolation protocol was used to isolate $2 \mathrm{a}$ as an oil $(89 \%)$. ${ }^{1} \mathrm{H}$ NMR $(400 \mathrm{~Hz}$, $\mathrm{CDCl}_{3}$ ): $\delta$ 7.28-7.19 (m, overlapping solvent, $\left.4 \mathrm{H}\right), 7.15(\mathrm{t}, J=7 \mathrm{~Hz}, 1 \mathrm{H}), 2.74(\mathrm{t}, J=8 \mathrm{~Hz}$, $2 \mathrm{H}), 1.22(\mathrm{~s}, 12 \mathrm{H}), 1.14(\mathrm{t}, J=8 \mathrm{~Hz}, 2 \mathrm{H}) \cdot{ }^{13} \mathrm{C}\left\{{ }^{1} \mathrm{H}\right\} \operatorname{NMR}\left(150.8 \mathrm{~Hz}, \mathrm{CDCl}_{3}\right): \delta 144.5,128.3$, 128.1, 125.6, 83.2, 30.1, 24.9. ${ }^{11} \mathrm{~B}$ NMR $\left(192.5 \mathrm{~Hz}, \mathrm{CDCl}_{3}\right): \delta 34.4$. These spectroscopic data correspond to reported data. ${ }^{3}$

\section{4,4,5,5-Tetramethyl-2-(4-methylphenethyl)-1,3,2-dioxaborolane (2b).}

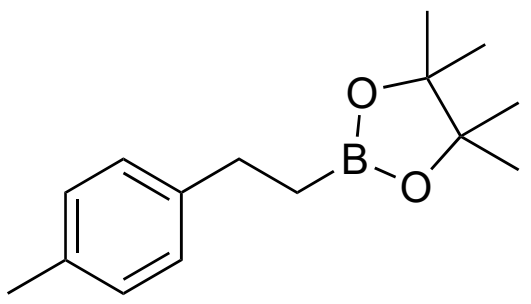

To a $20 \mathrm{~mL}$ vial equipped with a stir bar, (PPClP) $\mathrm{CoCl}_{2}$ (1) $(0.011 \mathrm{~g}, 0.014 \mathrm{mmol}, 1.0 \mathrm{~mol} \%)$, THF $(3 \mathrm{~mL})$, HBPin $(209.7 \mu \mathrm{L}, 1.44 \mathrm{mmol})$, and 4-methylstyrene $(190.4 \mu \mathrm{L}$, $1.44 \mathrm{mmol}$ ) were added and stirred for $1 \mathrm{~min}$. KBEt $3 \mathrm{H}(30.3$ $\mu \mathrm{L}, 1.0 \mathrm{M}$ solution in THF, $0.030 \mathrm{mmol}$ ) was added to the stirring solution via a glass syringe and the reaction was stirred at room temperature for $30 \mathrm{~min}$. Upon completion, the solvent was removed in vacuo. Hexamethylbenzene $(141.9 \mu \mathrm{L}, 1.0 \mathrm{M}$ solution in $\mathrm{CDCl}_{3}, 0.141 \mathrm{mmol}$ ) was added to remaining oily residue via a glass syringe, and the resulting solution was diluted further with $\mathrm{CDCl}_{3} .{ }^{1} \mathrm{H}$ NMR spectroscopy was used to determine the yield by integration of the methyl BPin resonance at $1.21 \mathrm{ppm}$ relative to the resonance of the internal standard (hexamethylbenzene, $2.23 \mathrm{ppm})\left({ }^{1} \mathrm{H}\right.$ NMR yield: $94 \%)$. The isolation protocol was used to isolate $\mathbf{2 b}$ as an oil $(85 \%)$. ${ }^{1} \mathrm{H}$ NMR $(600 \mathrm{~Hz}$, $\left.\mathrm{CDCl}_{3}\right): \delta 7.13(\mathrm{~m}, 4 \mathrm{H}), 2.72(\mathrm{t}, \mathrm{J}=8 \mathrm{~Hz}, 2 \mathrm{H}), 2.29(\mathrm{~s}, 3 \mathrm{H}), 1.21(\mathrm{~s}, 12 \mathrm{H}), 1.14(\mathrm{t}, J=8$ $\mathrm{Hz}, 2 \mathrm{H}) .{ }^{13} \mathrm{C}\left\{{ }^{1} \mathrm{H}\right\} \mathrm{NMR}\left(150.8 \mathrm{~Hz}, \mathrm{CDCl}_{3}\right): \delta 141.5,134.9,128.9,127.9,83.1,29.6,24.9$, 21.1. ${ }^{11} \mathrm{~B}$ NMR $\left(192.5 \mathrm{~Hz}, \mathrm{CDCl}_{3}\right): \delta 34.1$. These spectroscopic data correspond to reported data. ${ }^{3}$ 


\section{2-(4-methoxyphenethyl)-4,4,5,5-tetramethyl-1,3,2-dioxaborolane (2c).}<smiles>COc1ccc(CCB2OC(C)(C)C(C)(C)O2)cc1</smiles>

To a $20 \mathrm{~mL}$ vial equipped with a stir bar, (PPClP) $\mathrm{CoCl}_{2}$ (1) $(0.012 \mathrm{~g}, 0.015 \mathrm{mmol}, 1.0 \mathrm{~mol} \%)$, THF (3 mL), HBPin $(226.5 \mu \mathrm{L}, 1.56 \mathrm{mmol})$, and 4-vinylanisole $(207.6 \mu \mathrm{L}$, $1.56 \mathrm{mmol}$ ) were added and stirred for $1 \mathrm{~min}$. $\mathrm{KBEt}_{3} \mathrm{H}$ $(32.7 \mu \mathrm{L}, 1 \mathrm{M}$ in THF, $0.32 \mathrm{mmol})$ was added to the stirring solution via a glass syringe and the reaction was stirred at room temperature for $30 \mathrm{~min}$. Upon completion, the solvent was removed in vacuo. Hexamethylbenzene $\left(156.1 \mu \mathrm{L}, 1.0 \mathrm{M}\right.$ in $\mathrm{CDCl}_{3}, 0.156$ $\mathrm{mmol}$ ) was added to the remaining oily residue via a glass syringe, and the resulting solution was diluted further with $\mathrm{CDCl}_{3} .{ }^{1} \mathrm{H}$ NMR spectroscopy was used to determine the yield by integration of the methyl BPin resonance at $1.22 \mathrm{ppm}$ relative to the resonance of the internal standard (hexamethylbenzene, $2.23 \mathrm{ppm})\left({ }^{1} \mathrm{H}\right.$ NMR yield: $\left.92 \%\right) .{ }^{1} \mathrm{H}$ NMR $\left(400 \mathrm{~Hz}, \mathrm{CDCl}_{3}\right): \delta 7.13$ (d, $\left.J=8.4 \mathrm{~Hz}, 2 \mathrm{H}\right), 6.81(\mathrm{~d}, J=8.5 \mathrm{~Hz}, 2 \mathrm{H}), 3.77(\mathrm{~s}, 3 \mathrm{H}), 2.69$ (t, $J=8 \mathrm{~Hz}, 2 \mathrm{H}), 1.22(\mathrm{~s}, 12 \mathrm{H}), 1.11(\mathrm{t}, J=8 \mathrm{~Hz}, 2 \mathrm{H}) .{ }^{13} \mathrm{C}\left\{{ }^{1} \mathrm{H}\right\} \mathrm{NMR}\left(150.8 \mathrm{~Hz}, \mathrm{CDCl}_{3}\right): \delta$ 157.6, 136.7, 128.9, 113.7, 83.1, 55.3, 29.2, 24.9. ${ }^{11} \mathrm{~B}$ NMR $\left(192.5 \mathrm{~Hz}, \mathrm{CDCl}_{3}\right): \delta 34.2$. These spectroscopic data correspond to reported data. ${ }^{3}$

\section{2-(4-fluorophenethyl)-4,4,5,5-tetramethyl-1,3,2-dioxaborolane (2d).}

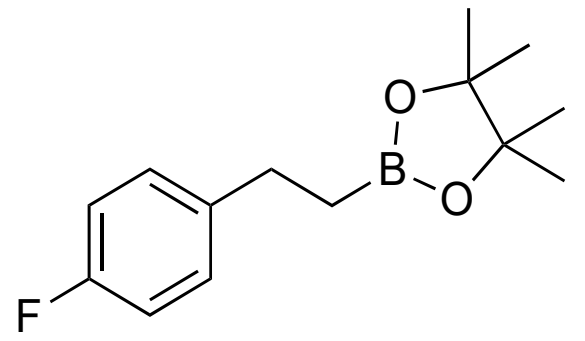

To a $20 \mathrm{~mL}$ vial equipped with a stir bar, (PPClP) $\mathrm{CoCl}_{2}$ (1) $(0.012 \mathrm{~g}, 0.015 \mathrm{mmol}, 1.0 \mathrm{~mol} \%)$, THF (3 mL), HBPin $(222.8 \mu \mathrm{L}, 1.54 \mathrm{mmol})$, and 4-fluorostyrene $(183.1 \mu \mathrm{L}$, $1.54 \mathrm{mmol}$ ) were added and stirred for $1 \mathrm{~min}$. $\mathrm{KBEt}_{3} \mathrm{H}$ $(32.2 \mu \mathrm{L}, 1.0 \mathrm{M}$ in THF, $0.32 \mathrm{mmol}$ ) was added to the stirring solution via a glass syringe and the reaction was stirred at room temperature for $30 \mathrm{~min}$. Upon completion, the solvent was removed in vacuo. Hexamethylbenzene $\left(154.8 \mu \mathrm{L}, 1.0 \mathrm{M}\right.$ in $\mathrm{CDCl}_{3}, 0.154 \mathrm{mmol}$ ) was added to the remaining oily residue via a glass syringe, and the resulting solution was diluted further with $\mathrm{CDCl}_{3}$. ${ }^{1} \mathrm{H} \mathrm{NMR}$ spectroscopy was used to determine the yield by integration of the methyl BPin resonance at $1.21 \mathrm{ppm}$ relative to the resonance of the internal standard (hexamethylbenzene, 2.23 ppm) ( ${ }^{1} \mathrm{H}$ NMR yield: $\left.92 \%\right) .{ }^{1} \mathrm{H}$ NMR $\left(400 \mathrm{~Hz}, \mathrm{CDCl}_{3}\right): \delta 7.15(\mathrm{~m}, 2 \mathrm{H}), 6.93(\mathrm{~m}, 2 \mathrm{H}), 2.71$ $(\mathrm{t}, J=7 \mathrm{~Hz}, 2 \mathrm{H}), 1.21(\mathrm{~s}, 12 \mathrm{H}), 1.11(\mathrm{t}, J=8 \mathrm{~Hz}, 2 \mathrm{H}) \cdot{ }^{13} \mathrm{C}\left\{{ }^{1} \mathrm{H}\right\} \mathrm{NMR}\left(150.8 \mathrm{~Hz}, \mathrm{CDCl}_{3}\right): \delta$ $161.2(\mathrm{~d}, J=960 \mathrm{~Hz}), 140.1(\mathrm{~d}, J=2.3 \mathrm{~Hz}), 129.4(\mathrm{~d}, J=30 \mathrm{~Hz}), 114.9(\mathrm{~d}, J=84 \mathrm{~Hz})$, 83.2, 29.3, 24.9. ${ }^{11} \mathrm{~B}$ NMR $\left(192.5 \mathrm{~Hz}, \mathrm{CDCl}_{3}\right): \delta 33.8 .{ }^{19} \mathrm{~F}\left\{{ }^{1} \mathrm{H}\right\} \mathrm{NMR}\left(470.6 \mathrm{~Hz}, \mathrm{CDCl}_{3}\right): \delta$ -118.4. These spectroscopic data correspond to reported data. ${ }^{3}$

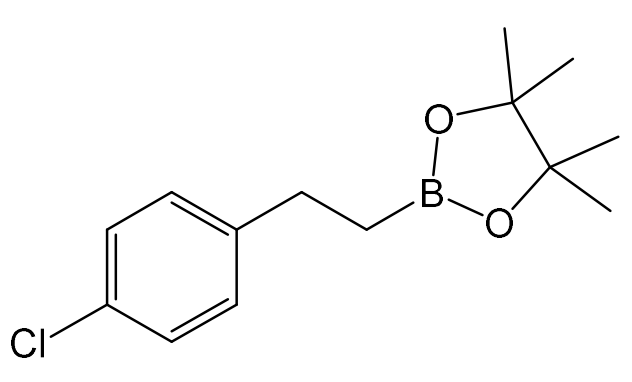

2-(4-chlorophenethyl)-4,4,5,5-tetramethyl-1,3,2dioxaborolane (2e).

To a $20 \mathrm{~mL}$ vial equipped with a stir bar, (PPClP) $\mathrm{CoCl}_{2}$ (1) $(0.010 \mathrm{~g}, 0.012 \mathrm{mmol}, 1.0 \mathrm{~mol} \%)$, THF (3 mL), HBPin (179.8 $\mu \mathrm{L}, 1.24 \mathrm{mmol})$, and 4chlorostyrene $(157.5 \mu \mathrm{L}, 1.24 \mathrm{mmol})$ were added 
and stirred for $1 \mathrm{~min}$. $\mathrm{KBEt}_{3} \mathrm{H}(24.8 \mu \mathrm{L}, 1.0 \mathrm{M}$ in THF, $0.025 \mathrm{mmol})$ was added to the stirring solution via a glass syringe and the reaction was stirred at room temperature for $30 \mathrm{~min}$. Upon completion, the solvent was removed in vacuo. Hexamethylbenzene $(0.0202 \mathrm{~g}, 0.124 \mathrm{mmol})$ was added to the remaining oily residue as a solution in $\mathrm{CDCl}_{3}$. ${ }^{1} \mathrm{H}$ NMR spectroscopy was used to determine the yield by integration of the methylene $\mathrm{CH}_{2}$ resonance at $2.72 \mathrm{ppm}$ relative to the resonance of the internal standard (hexamethylbenzene, $2.23 \mathrm{ppm})\left({ }^{1} \mathrm{H}\right.$ NMR yield: $\left.74 \%\right) .{ }^{1} \mathrm{H}$ NMR $\left(400 \mathrm{~Hz}, \mathrm{CDCl}_{3}\right): \delta 7.17$ (overlapping, 4H), $2.72(\mathrm{~s}, 2 \mathrm{H}), 1.21$ (overlapping, 14H). These spectroscopic data correspond to reported data. ${ }^{3}$

\section{2-(4-bromophenethyl)-4,4,5,5-tetramethyl-1,3,2-dioxaborolane (2f).}

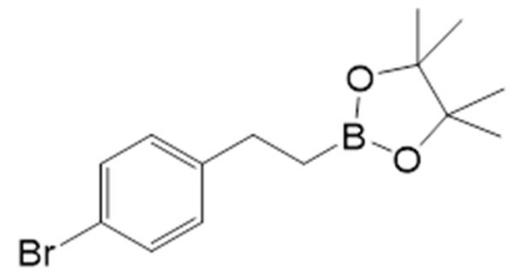

To a $20 \mathrm{~mL}$ vial equipped with a stir bar, (PPClP) $\mathrm{CoCl}_{2}$ (1) $(0.011 \mathrm{~g}, 0.015 \mathrm{mmol}, 1.0 \mathrm{~mol} \%)$, THF (3 mL), HBPin (211.4 $\mu \mathrm{L}, 1.46 \mathrm{mmol})$, and 4-bromostyrene $(190.9 \mu \mathrm{L}, 1.46 \mathrm{mmol})$ were added and stirred for $1 \mathrm{~min}$. $\mathrm{KBEt}_{3} \mathrm{H}(29.1 \mu \mathrm{L}, 1.0 \mathrm{M}$ in THF, $0.29 \mathrm{mmol}$ ) was added to the stirring solution via a glass syringe and the reaction was stirred at room temperature for $30 \mathrm{~min}$. Upon completion, the solvent was removed in vacuo. Hexamethylbenzene $\left(145.7 \mu \mathrm{L}, 1.0 \mathrm{M}\right.$ in $\left.\mathrm{CDCl}_{3}, 0.146 \mathrm{mmol}\right)$ was added to the remaining oily residue via a glass syringe, and the resulting solution was diluted further with $\mathrm{CDCl}_{3}$. ${ }^{1} \mathrm{H}$ NMR spectroscopy was used to determine the yield by integration of the methyl BPin resonance at $1.20 \mathrm{ppm}$ relative to the resonance of the internal standard (hexamethylbenzene, $2.23 \mathrm{ppm})\left({ }^{1} \mathrm{H}\right.$ NMR yield: $\left.48 \%\right) .{ }^{1} \mathrm{H}$ NMR $\left(400 \mathrm{~Hz}, \mathrm{CDCl}_{3}\right): \delta 7.36$ $(\mathrm{m}, 2 \mathrm{H}), 7.07(\mathrm{~m}, 2 \mathrm{H}), 2.69(\mathrm{~m}, 2 \mathrm{H}), 1.20(\mathrm{~s}, 12 \mathrm{H}), 1.10(\mathrm{~m}, 2 \mathrm{H})$. These spectroscopic data correspond to reported data. ${ }^{3}$

\section{2-(Cyclohexylmethyl)-4,4,5,5-tetramethyl-1,3,2-dioxaborolane (2g).}

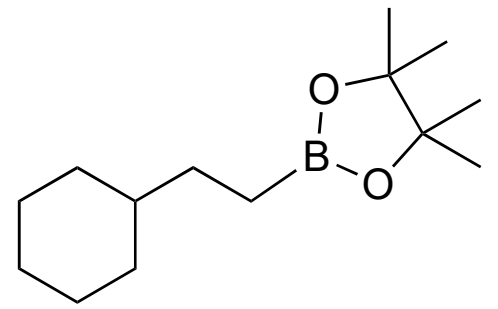

To a $20 \mathrm{~mL}$ vial equipped with a stir bar, (PPClP) $\mathrm{CoCl}_{2}$ (1) (0.012 g, $0.015 \mathrm{mmol}, 1.0 \mathrm{~mol} \%)$, THF (3 mL), HBPin (207.8 $\mu \mathrm{L}, 1.54 \mathrm{mmol})$, and cyclohexylethene $(187.5 \mu \mathrm{L}, 1.54 \mathrm{mmol})$ were added and stirred for $1 \mathrm{~min}$. $\mathrm{KBEt}_{3} \mathrm{H}(30.1 \mu \mathrm{L}, 1.0 \mathrm{M}$ in THF, $0.032 \mathrm{mmol}$ ) was added to the stirring solution via a glass syringe and the reaction was stirred at room temperature for $30 \mathrm{~min}$. Upon completion, the solvent was removed in vacuo. Hexamethylbenzene $\left(154.9 \mu \mathrm{L}, 1.0 \mathrm{M}\right.$ in $\left.\mathrm{CDCl}_{3}, 0.154 \mathrm{mmol}\right)$ was added to the remaining oil via a glass syringe, and the resulting solution was diluted further with $\mathrm{CDCl}_{3} .{ }^{1} \mathrm{H}$ NMR spectroscopy was used to determine the yield by integration of the methyl BPin resonance at $1.23 \mathrm{ppm}$ relative to the resonance of the internal standard (hexamethylbenzene, $2.23 \mathrm{ppm})\left({ }^{1} \mathrm{H}\right.$ NMR yield: $\left.99 \%\right) .{ }^{1} \mathrm{H}$ NMR $(400 \mathrm{~Hz}$, $\left.\mathrm{CDCl}_{3}\right): \delta 1.74-1.59(\mathrm{~m}, 5 \mathrm{H}), 1.31-1.26(\mathrm{~m}, 2 \mathrm{H}), 1.23(\mathrm{~s}, 12 \mathrm{H}), 1.21-1.08(\mathrm{~m}, 4 \mathrm{H}), 0.87-$ $0.79(\mathrm{~m}, 2 \mathrm{H}), 0.74(\mathrm{t}, \mathrm{J}=8 \mathrm{~Hz}, 2 \mathrm{H}) .{ }^{13} \mathrm{C}\left\{{ }^{1} \mathrm{H}\right\} \operatorname{NMR}\left(150.8 \mathrm{~Hz}, \mathrm{CDCl}_{3}\right): \delta 82.9,40.1,33.1$, 31.5, 26.9, 26.5, 24.9. ${ }^{11} \mathrm{~B}$ NMR $\left(192.5 \mathrm{~Hz}, \mathrm{CDCl}_{3}\right): \delta 34.2$. These spectroscopic data correspond to reported data. ${ }^{3}$ 


\section{2-hex-1-yl-4,4,5,5-tetramethyl-1,3,2-dioxaborolane (2h).}

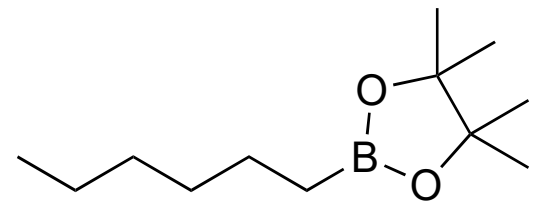

To a $20 \mathrm{~mL}$ vial equipped with a stir bar, (PPClP) $\mathrm{CoCl}_{2}$ (1) (0.011 g, $0.014 \mathrm{mmol}, 1.0 \mathrm{~mol} \%)$, THF (3 mL), HBPin $(205.9 \mu \mathrm{L}, 1.41 \mathrm{mmol})$, and 1-hexene $(176.0 \mu \mathrm{L}, 1.41$ $\mathrm{mmol})$ were added and stirred for $1 \mathrm{~min}$. $\mathrm{KBEt}_{3} \mathrm{H}(29.8 \mu \mathrm{L}$, $1.0 \mathrm{M}$ in THF, $0.029 \mathrm{mmol}$ ) was added to the stirring solution via a glass syringe and the reaction was stirred at room temperature for $30 \mathrm{~min}$. Upon completion, the solvent was removed in vacuo. Hexamethylbenzene $(141.9 \mu \mathrm{L}, 1.0$ $\mathrm{M}$ in $\mathrm{CDCl}_{3}, 0.141 \mathrm{mmol}$ ) was added to the remaining oily residue via a glass syringe, and the resulting solution was diluted further with $\mathrm{CDCl}_{3}$. ${ }^{1} \mathrm{H}$ NMR spectroscopy was used to determine the yield by integration of the methyl BPin resonance at $1.23 \mathrm{ppm}$ relative to the resonance of the internal standard (hexamethylbenzene, $2.23 \mathrm{ppm})\left({ }^{1} \mathrm{H}\right.$ NMR yield: 98\%). ${ }^{1} \mathrm{H}$ NMR $\left(600 \mathrm{~Hz}, \mathrm{CDCl}_{3}\right): \delta 1.39(\mathrm{~m}, 2 \mathrm{H}), 1.30-1.25(\mathrm{~m}, 6 \mathrm{H}), 1.23(\mathrm{~s}, 12 \mathrm{H}), 0.86(\mathrm{t}$, $J=8 \mathrm{~Hz}, 3 \mathrm{H}), 0.76(\mathrm{t}, J=8 \mathrm{~Hz}, 2 \mathrm{H}) .{ }^{13} \mathrm{C}\left\{{ }^{1} \mathrm{H}\right\} \mathrm{NMR}\left(150.8 \mathrm{~Hz}, \mathrm{CDCl}_{3}\right): \delta 82.9,32.2,31.7$, 24.9, 24.1, 22.7, 14.2. ${ }^{11} \mathrm{~B}$ NMR $\left(192.5 \mathrm{~Hz}, \mathrm{CDCl}_{3}\right): \delta 34.2$. These spectroscopic data correspond to reported data. ${ }^{4}$

\section{4,4,5,5-Tetramethyl-2-(3-phenylpropyl)-1,3,2-dioxaborolane (2i).}<smiles>CC1(C)OB(CCCc2ccccc2)OC1(C)C</smiles>

To a $20 \mathrm{~mL}$ vial equipped with a stir bar, (PPClP) $\mathrm{CoCl}_{2}$ (1) (0.010 g, $0.013 \mathrm{mmol}, 1.0 \mathrm{~mol} \%)$, THF (3 mL), HBPin (192.8 $\mu \mathrm{L}, 1.29 \mathrm{mmol})$, and allylbenzene $(176.1 \mu \mathrm{L}, 1.29$ $\mathrm{mmol})$ were added and stirred for $1 \mathrm{~min}$. KBEt $3 \mathrm{H}(27.9 \mu \mathrm{L}$, $1.0 \mathrm{M}$ in THF, $0.027 \mathrm{mmol}$ ) was added to the stirring solution via a glass syringe and the reaction was stirred at room temperature for $30 \mathrm{~min}$. Upon completion, the solvent was removed in vacuo. Hexamethylbenzene $(129.0 \mu \mathrm{L}, 1.0$ $\mathrm{M}$ in $\mathrm{CDCl}_{3}, 0.129 \mathrm{mmol}$ ) was added to the remaining oily residue via a glass syringe, and the resulting solution was diluted further with $\mathrm{CDCl}_{3}$. ${ }^{1} \mathrm{H}$ NMR spectroscopy was used to determine the yield by integration of the methyl BPin resonance at $1.24 \mathrm{ppm}$ relative to the resonance of the internal standard (hexamethylbenzene, $2.23 \mathrm{ppm})\left({ }^{1} \mathrm{H}\right.$ NMR yield: 97\%). ${ }^{1} \mathrm{H}$ NMR $\left(400 \mathrm{~Hz}, \mathrm{CDCl}_{3}\right): \delta 7.25(\mathrm{~m}, 2 \mathrm{H}), 7.18(\mathrm{~m}, 3 \mathrm{H}), 2.60(\mathrm{t}, J=7 \mathrm{~Hz}, 2 \mathrm{H}), 1.79-$ $1.68(\mathrm{~m}, 2 \mathrm{H}), 1.24(\mathrm{~s}, 12 \mathrm{H}), 0.83(\mathrm{t}, J=7 \mathrm{~Hz}, 2 \mathrm{H}) .{ }^{13} \mathrm{C}\left\{{ }^{1} \mathrm{H}\right\} \mathrm{NMR}\left(150.8 \mathrm{~Hz}, \mathrm{CDCl}_{3}\right): \delta$ 142.8, 128.6, 128.3, 125.6, 83.1, 38.7, 26.2, 24.9. ${ }^{11} \mathrm{~B}$ NMR $\left(192.5 \mathrm{~Hz}, \mathrm{CDCl}_{3}\right): \delta 34.1$. These spectroscopic data correspond to reported data. ${ }^{3}$

\section{2-(3,3-dimethylbutyl)-4,4,5,5-tetramethyl-1,3,2-dioxaborolane (2j).}

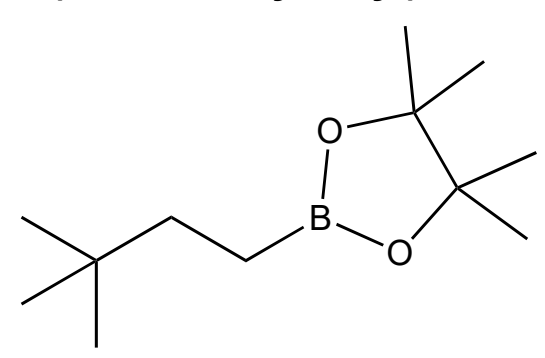

To a $20 \mathrm{~mL}$ vial equipped with a stir bar, (PPClP) $\mathrm{CoCl}_{2}$ (1) (0.013 g, $0.017 \mathrm{mmol}, 1.0 \mathrm{~mol} \%)$, THF (3 mL), HBPin $(254.6 \mu \mathrm{L}, 1.75 \mathrm{mmol})$, and 1-butene $(226.2 \mu \mathrm{L}, 1.75$ $\mathrm{mmol})$ were added and stirred for $1 \mathrm{~min}$. $\mathrm{KBEt}_{3} \mathrm{H}(36.8 \mu \mathrm{L}$, $1.0 \mathrm{M}$ in THF, $0.036 \mathrm{mmol}$ ) was added to the stirring solution via a glass syringe and the reaction was stirred at room temperature for $30 \mathrm{~min}$. Upon completion, the solvent was removed in vacuo. Hexamethylbenzene

$\left(167.7 \mu \mathrm{L}, 1.0 \mathrm{M}\right.$ in $\mathrm{CDCl}_{3}, 0.167 \mathrm{mmol}$ ) was added to the remaining oily residue via a 
glass syringe, and the resulting solution was diluted further with $\mathrm{CDCl}_{3} .{ }^{1} \mathrm{H} \mathrm{NMR}$ spectroscopy was used to determine the yield by integration of the methyl BPin resonance at $1.24 \mathrm{ppm}$ relative to the resonance of the internal standard (hexamethylbenzene, 2.23 ppm) ( ${ }^{1} \mathrm{H}$ NMR yield: $\left.83 \%\right) .{ }^{1} \mathrm{H}$ NMR $\left(400 \mathrm{~Hz}, \mathrm{CDCl}_{3}\right): \delta 1.29(\mathrm{~m}, 2 \mathrm{H}), 1.24(\mathrm{~s}, 12 \mathrm{H}), 0.84$ $(\mathrm{s}, 9 \mathrm{H}), 0.69(\mathrm{~m}, 2 \mathrm{H}) .{ }^{13} \mathrm{C}\left\{{ }^{1} \mathrm{H}\right\} \mathrm{NMR}\left(100.6 \mathrm{~Hz}, \mathrm{CDCl}_{3}\right): \delta 83.0,37.8,30.9,28.9,24.9 .{ }^{11} \mathrm{~B}$ NMR $\left(192.5 \mathrm{~Hz}, \mathrm{CDCl}_{3}\right): \delta 34.4$. These spectroscopic data correspond to reported data. ${ }^{5}$

\section{4,4,5,5-tetramethyl-2-(3-phenoxypropyl)-1,3,2-dioxaborolane (2k).}

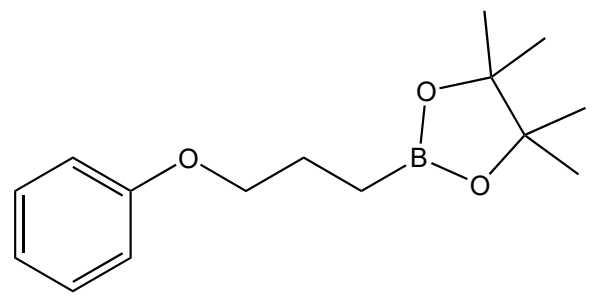

To a $20 \mathrm{~mL}$ vial equipped with a stir bar, $(\mathrm{PPCl}) \mathrm{CoCl}_{2}$ (1) $(0.010 \mathrm{~g}, 0.013 \mathrm{mmol}, 1.0 \mathrm{~mol} \%)$, THF $(3 \mathrm{~mL})$, HBPin $(200.3 \mu \mathrm{L}, 1.38 \mathrm{mmol})$, and allylphenylether $(189.4 \mu \mathrm{L}, 1.38 \mathrm{mmol})$ were added and stirred for $1 \mathrm{~min}$. $\mathrm{KBEt}_{3} \mathrm{H}(29.0 \mu \mathrm{L}, 1.0 \mathrm{M}$ in THF, $0.029 \mathrm{mmol})$ was added to the stirring solution via a glass syringe and the reaction was stirred at room temperature for $30 \mathrm{~min}$. Upon completion, the solvent was removed in vacuo. Hexamethylbenzene $(129.0 \mu \mathrm{L}, 1.0$ $\mathrm{M}$ in $\mathrm{CDCl}_{3}, 0.129 \mathrm{mmol}$ ) was added to the remaining oily residue via a glass syringe, and the resulting solution was diluted further with $\mathrm{CDCl}_{3}$. ${ }^{1} \mathrm{H}$ NMR spectroscopy was used to determine the yield by integration of the methyl BPin resonance at $1.25 \mathrm{ppm}$ relative to the resonance of the internal standard (hexamethylbenzene, $2.23 \mathrm{ppm})\left({ }^{1} \mathrm{H}\right.$ NMR yield: $8 \%) .{ }^{1} \mathrm{H} \mathrm{NMR}\left(400 \mathrm{~Hz}, \mathrm{CDCl}_{3}\right): \delta 2$ aromatic protons hidden under allylphenylether peaks, $3.94(\mathrm{t}, J=6.6 \mathrm{~Hz}, 2 \mathrm{H}), 1.90(\mathrm{~m}, 2 \mathrm{H}), 1.25(\mathrm{~s}, 12 \mathrm{H}), 0.92(\mathrm{t}, J=7.4 \mathrm{~Hz}, 2 \mathrm{H})$. Due to low conversion, ${ }^{13} \mathrm{C}\left\{{ }^{1} \mathrm{H}\right\}$ and ${ }^{11} \mathrm{~B}$ NMR spectra were not collected. These spectroscopic data correspond to reported data. ${ }^{4}$

\section{2-(hex-5-en-2-yloxy)pinacolborane (2l).}

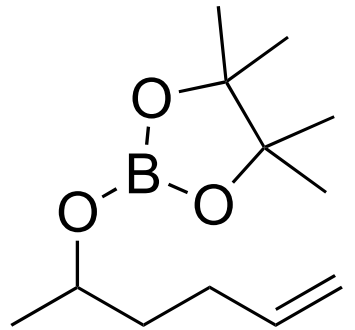

To a $20 \mathrm{~mL}$ vial equipped with a stir bar, (PPClP) $\mathrm{CoCl}_{2}(1)(0.010 \mathrm{~g}$, $0.013 \mathrm{mmol}, 1.0 \mathrm{~mol} \%)$, THF ( $3 \mathrm{~mL})$, HBPin $(200.3 \mu \mathrm{L}, 1.38 \mathrm{mmol})$, and 5-hexen-2-one $(189.4 \mu \mathrm{L}, 1.38 \mathrm{mmol})$ were added and stirred for $1 \mathrm{~min}$. KBEt $3 \mathrm{H}(29.0 \mu \mathrm{L}, 1.0 \mathrm{M}$ in THF, $0.029 \mathrm{mmol})$ was added to the stirring solution via a glass syringe and the reaction was stirred at room temperature for $30 \mathrm{~min}$. Upon completion, the solvent was removed in vacuo. Hexamethylbenzene $\left(129.0 \mu \mathrm{L}, 1.0 \mathrm{M}\right.$ in $\mathrm{CDCl}_{3}$, $0.129 \mathrm{mmol}$ ) was added to the remaining oily residue via a glass syringe, and the resulting solution was diluted further with $\mathrm{CDCl}_{3} .{ }^{1} \mathrm{H}$ NMR spectroscopy was used to determine the yield by integration of the methyl BPin resonance at $1.06 \mathrm{ppm}$ relative to the resonance of the internal standard (hexamethylbenzene, $2.23 \mathrm{ppm})\left({ }^{1} \mathrm{H}\right.$ NMR yield: $85 \%) .{ }^{1} \mathrm{H}$ NMR $\left(400 \mathrm{~Hz}, \mathrm{C}_{6} \mathrm{D}_{6}\right): \delta 5.76(\mathrm{~m}, 1 \mathrm{H}), 5.05-4.93$ (m, two overlapping signals, 2H), $4.34(\mathrm{~m}, 1 \mathrm{H}), 2.11(\mathrm{~m}, 2 \mathrm{H}), 1.63(\mathrm{~m}, 1 \mathrm{H}), 1.41(\mathrm{~m}, 1 \mathrm{H}), 1.17(\mathrm{~m}, 3 \mathrm{H}), 1.06$ $(\mathrm{s}, 12 \mathrm{H})$. These spectroscopic data correspond to reported data. ${ }^{6}$ 
Catalytic hydroboration of 5-hexen-2-one with two equivalents of HBPin.

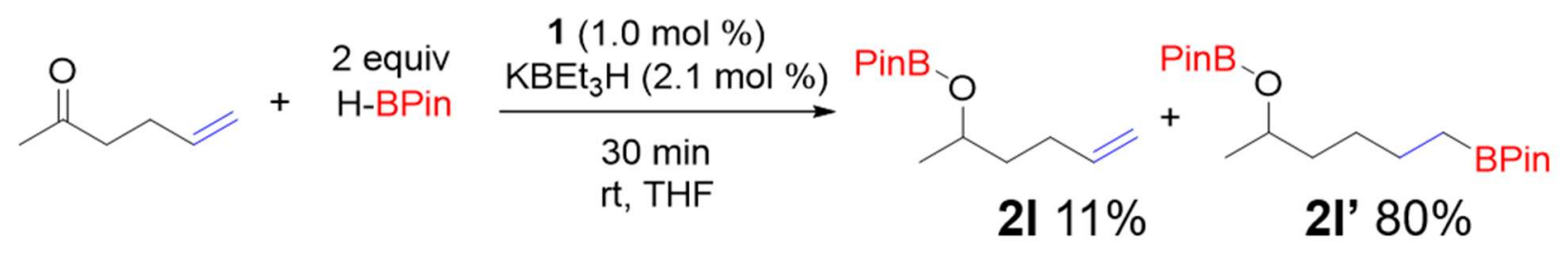

To a $20 \mathrm{~mL}$ vial equipped with a stir bar, (PPClP)CoCl $2(1)(0.012 \mathrm{~g}, 0.015 \mathrm{mmol}, 1.0 \mathrm{~mol}$ $\%)$, THF (3 mL), HBPin (441.8 $\mu \mathrm{L}, 3.04 \mathrm{mmol})$, and 5-hexen-2-one $(171.4 \mu \mathrm{L}, 1.54 \mathrm{mmol})$ were added and stirred for $1 \mathrm{~min}$. $\mathrm{KBEt}_{3} \mathrm{H}(30.2 \mu \mathrm{L}, 1.0 \mathrm{M}$ in THF, $0.030 \mathrm{mmol})$ was added to the stirring solution via a glass syringe and the reaction was stirred at room temperature for $30 \mathrm{~min}$. Upon completion, the solvent was removed in vacuo. Hexamethylbenzene $\left(152.0 \mu \mathrm{L}, 1.0 \mathrm{M}\right.$ in $\mathrm{CDCl}_{3}, 0.152 \mathrm{mmol}$ ) was added to the remaining oily residue via a glass syringe, and the resulting solution was diluted further with $\mathrm{CDCl}_{3} .{ }^{1} \mathrm{H} \mathrm{NMR}$ spectroscopy was used to determine the yield by integration of the methine proton resonance at $4.13 \mathrm{ppm}$ relative to the resonance of the internal standard (hexamethylbenzene, $2.23 \mathrm{ppm}$ ) ('H NMR yields: 80\% (2I'), 11\% (2I)).

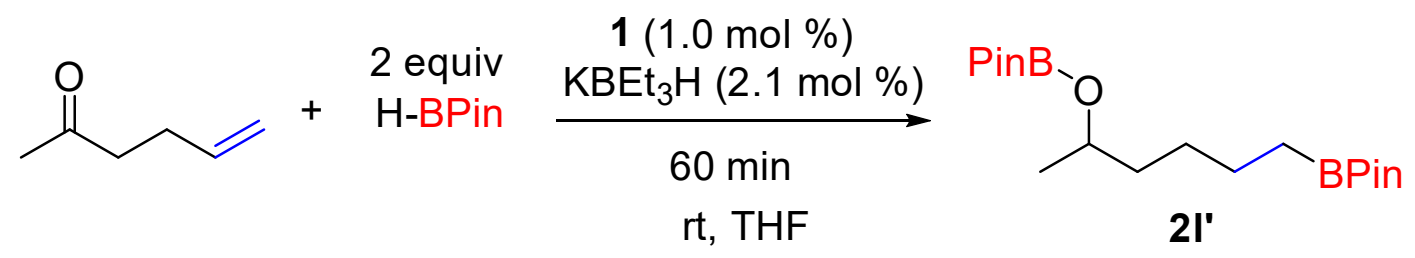

To a $20 \mathrm{~mL}$ vial equipped with a stir bar, (PPClP)CoCl $2(1)(0.012 \mathrm{~g}, 0.015 \mathrm{mmol}, 1.0 \mathrm{~mol}$ $\%)$, THF (3 mL), HBPin (445.6 $\mu \mathrm{L}, 3.07 \mathrm{mmol})$, and 5-hexen-2-one $(178.0 \mu \mathrm{L}, 1.54 \mathrm{mmol})$ were added and stirred for $1 \mathrm{~min}$. $\mathrm{KBEt}_{3} \mathrm{H}(30.8 \mu \mathrm{L}, 1.0 \mathrm{M}$ in THF, $0.031 \mathrm{mmol})$ was added to the stirring solution via a glass syringe and the reaction was stirred at room temperature for $1 \mathrm{~h}$. Upon completion, the solvent was removed in vacuo. Hexamethylbenzene (153.6 $\mu \mathrm{L}, 1.0 \mathrm{M}$ in $\mathrm{CDCl}_{3}, 0.154 \mathrm{mmol}$ ) was added to the remaining oily residue via a glass syringe, and the resulting solution was diluted further with $\mathrm{CDCl}_{3} .{ }^{1} \mathrm{H}$ NMR spectroscopy was used to determine the yield by integration of the methine resonance at $4.13 \mathrm{ppm}$ relative to the resonance of the internal standard (hexamethylbenzene, $2.23 \mathrm{ppm})\left({ }^{1} \mathrm{H}\right.$ NMR yield: $98 \%) .{ }^{1} \mathrm{H}$ NMR of $2 \mathrm{I}^{\prime}\left(400 \mathrm{~Hz}, \mathrm{CDCl}_{3}\right): \delta 4.13(\mathrm{~m}, 1 \mathrm{H}), 1.49(\mathrm{~m}, 2 \mathrm{H}), 1.38(\mathrm{~m}$, $4 \mathrm{H}), 1.20(\mathrm{~s}, 24 \mathrm{H}), 1.14(\mathrm{~m}, 3 \mathrm{H}), 0.74(\mathrm{~m}, 2 \mathrm{H})$. 


\section{NMR Spectra:}

Figure S1. ${ }^{1} \mathrm{H}$ NMR spectrum of $2 \mathrm{a}\left(400 \mathrm{~Hz}, \mathrm{CDCl}_{3}\right)$. Stars denote $\mathrm{CHCl}_{3}$ residual solvent.
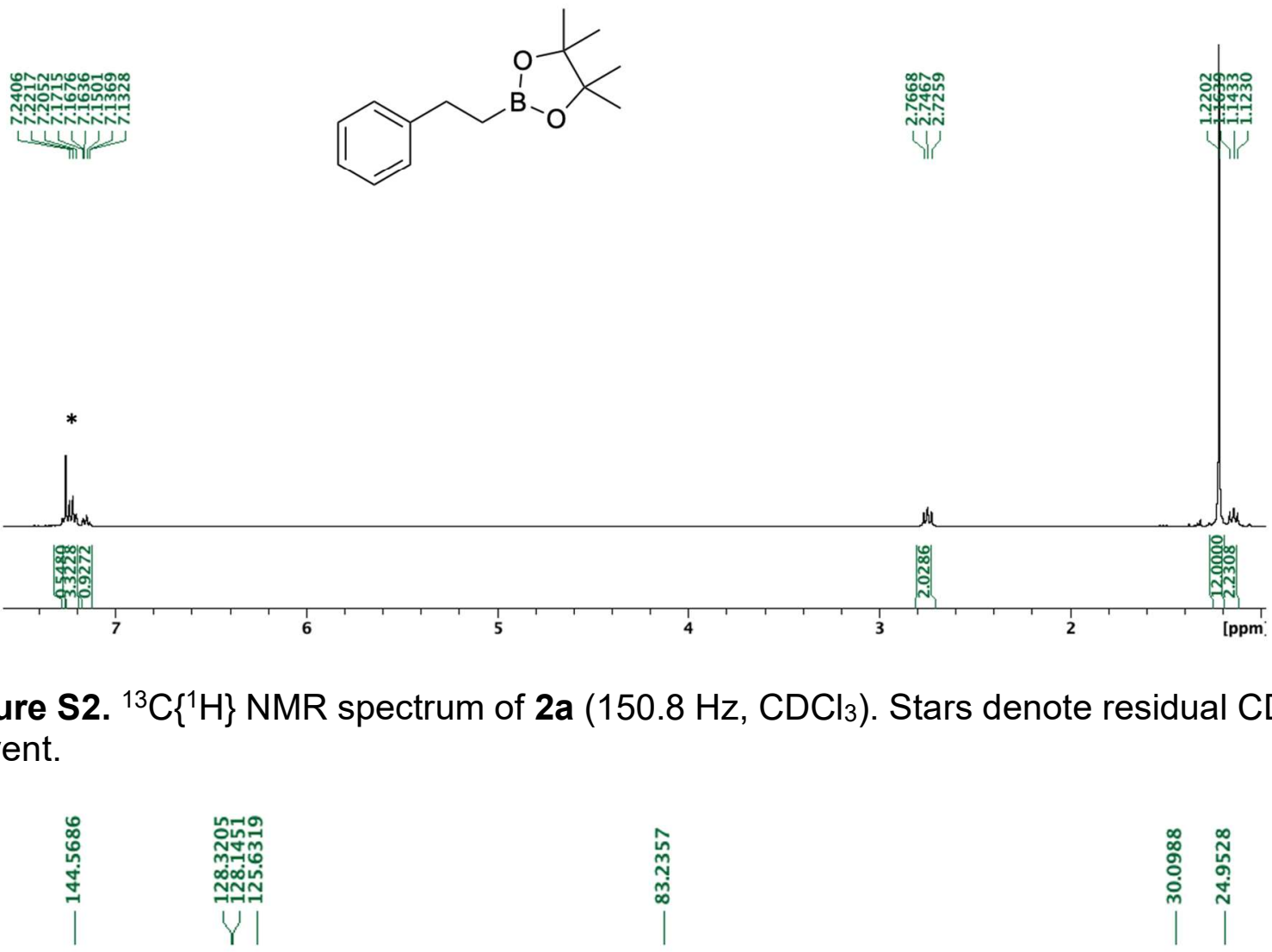

Figure S2. ${ }^{13} \mathrm{C}\left\{{ }^{1} \mathrm{H}\right\}$ NMR spectrum of $\mathbf{2 a}\left(150.8 \mathrm{~Hz}, \mathrm{CDCl}_{3}\right)$. Stars denote residual $\mathrm{CDCl}_{3}$ solvent.

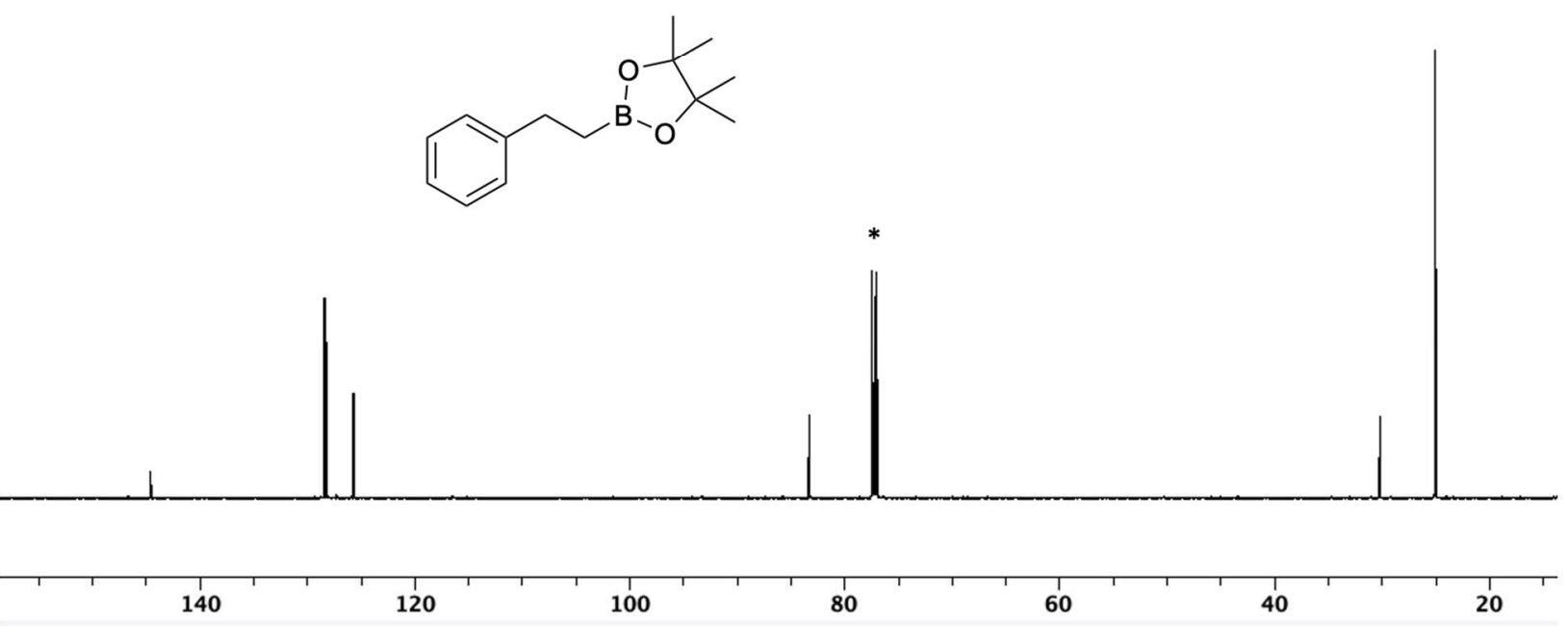


Figure S3. ${ }^{11} \mathrm{~B}$ NMR spectrum of $2 \mathrm{a}\left(192.5 \mathrm{~Hz}, \mathrm{CDCl}_{3}\right)$.

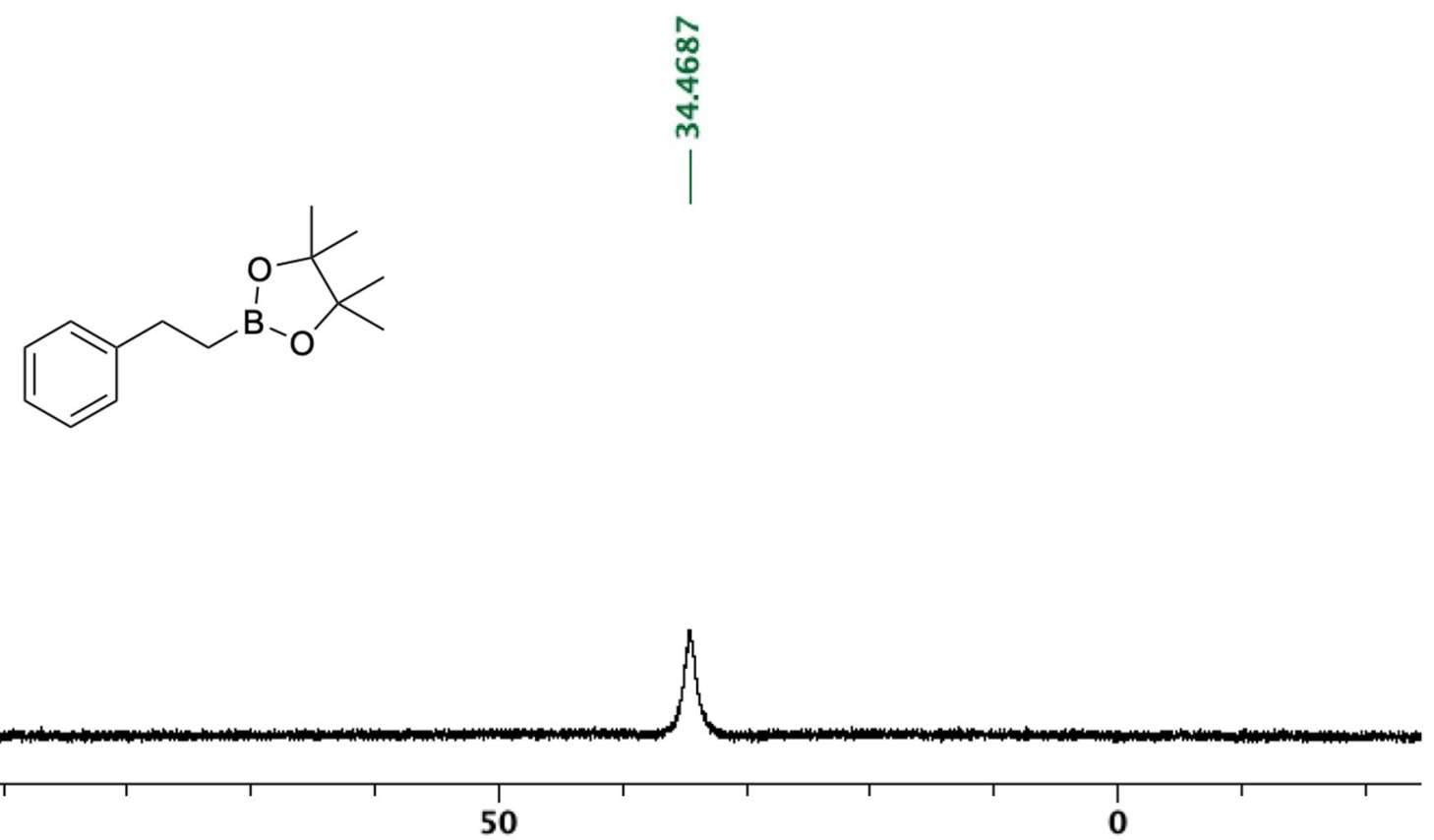

Figure S4. ${ }^{1} \mathrm{H}$ NMR spectrum of $\mathbf{2} \mathbf{b}\left(600 \mathrm{~Hz}, \mathrm{CDCl}_{3}\right)$. Stars denote residual $\mathrm{CHCl}_{3}$ solvent.

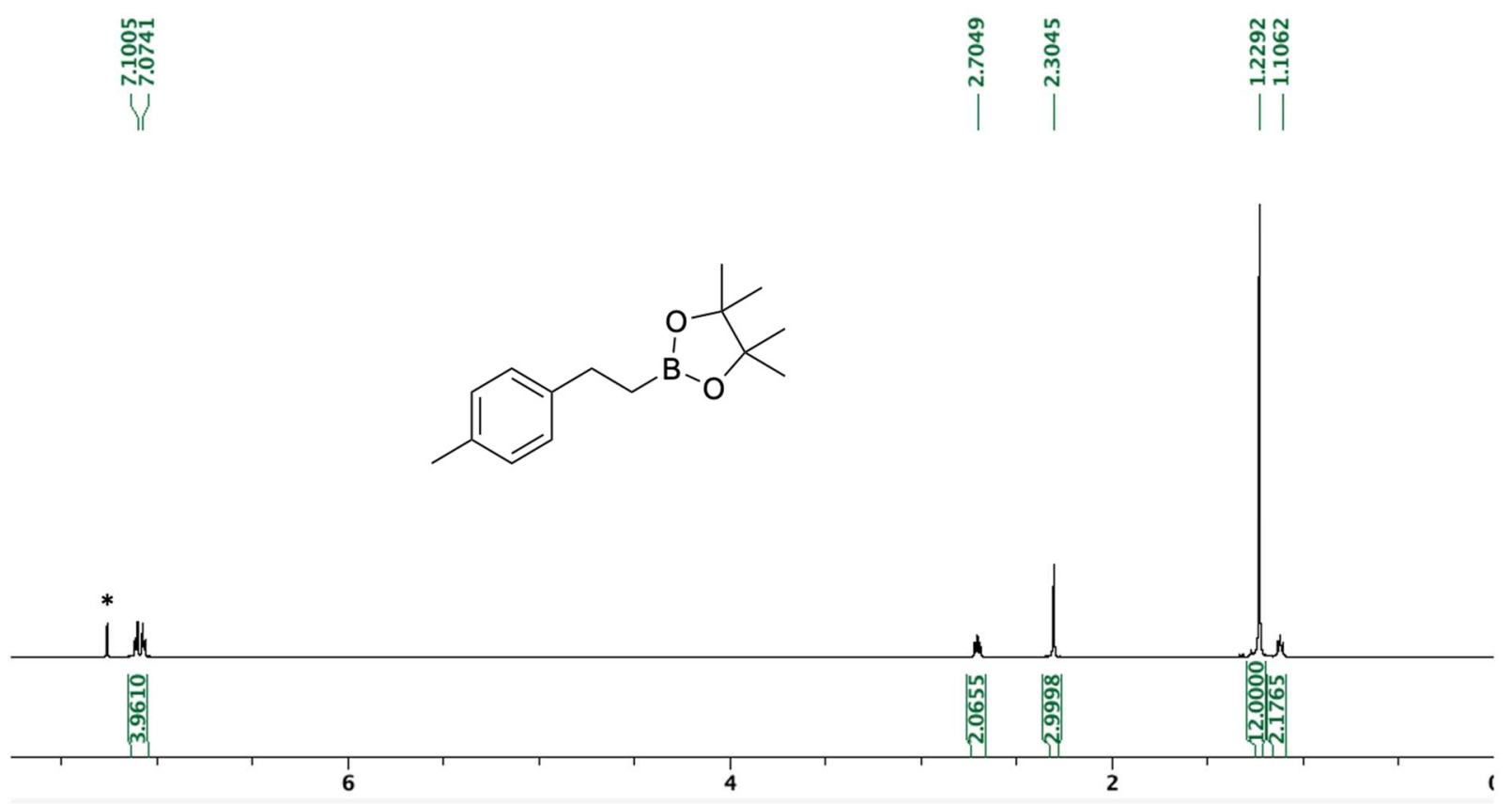


Figure S5. ${ }^{13} \mathrm{C}\left\{{ }^{1} \mathrm{H}\right\}$ NMR spectrum of $\mathbf{2} \mathbf{b}(150.8 \mathrm{~Hz}, \mathrm{CDCl} 3)$. Stars denote residual $\mathrm{CDCl}_{3}$ solvent.

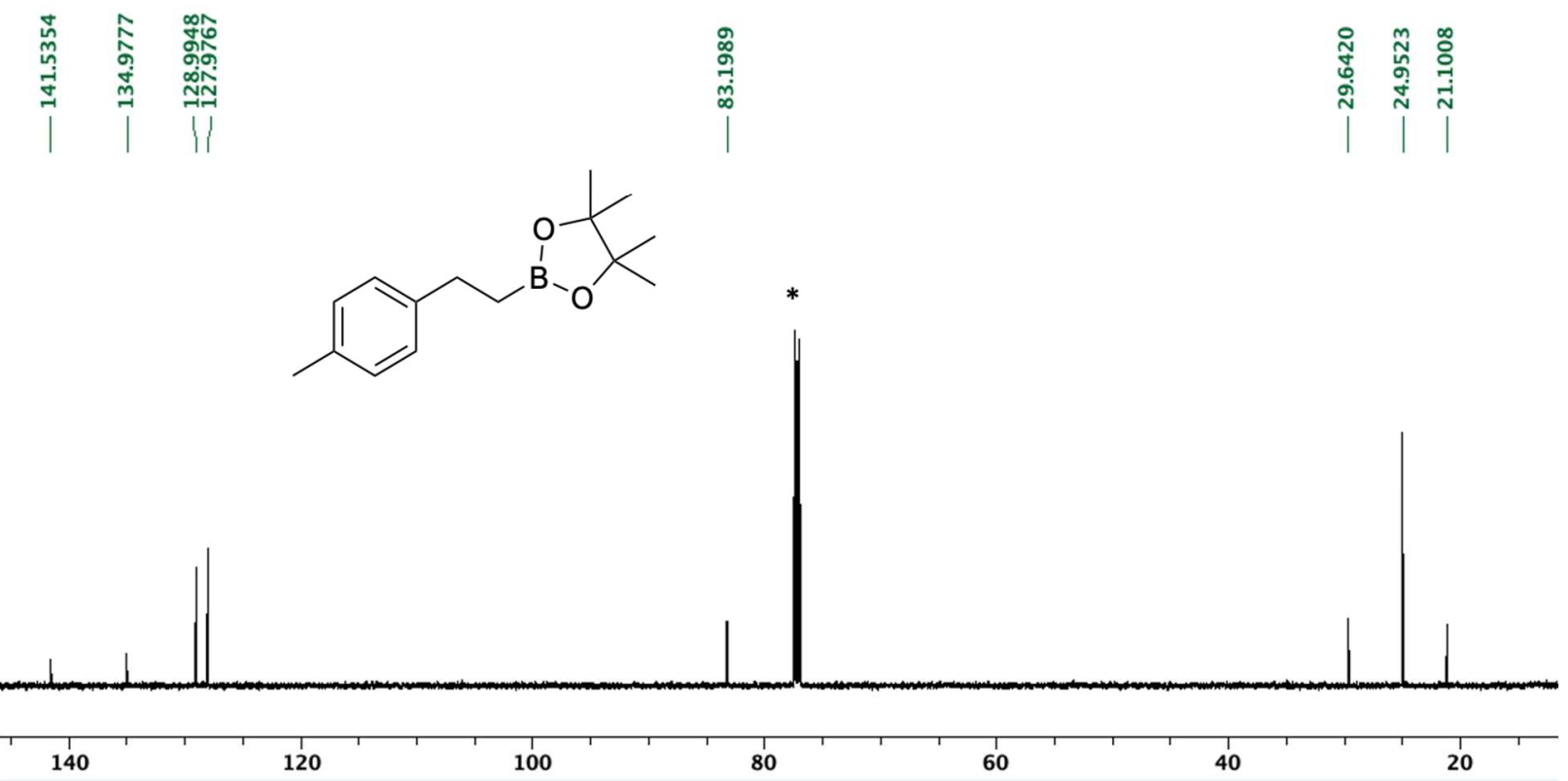

Figure S6. ${ }^{11} \mathrm{~B}$ NMR spectrum of $\mathbf{2 b}\left(192.5 \mathrm{~Hz}, \mathrm{CDCl}_{3}\right)$.<smiles>Cc1ccc(CCB2OC(C)(C)C(C)(C)O2)cc1</smiles>
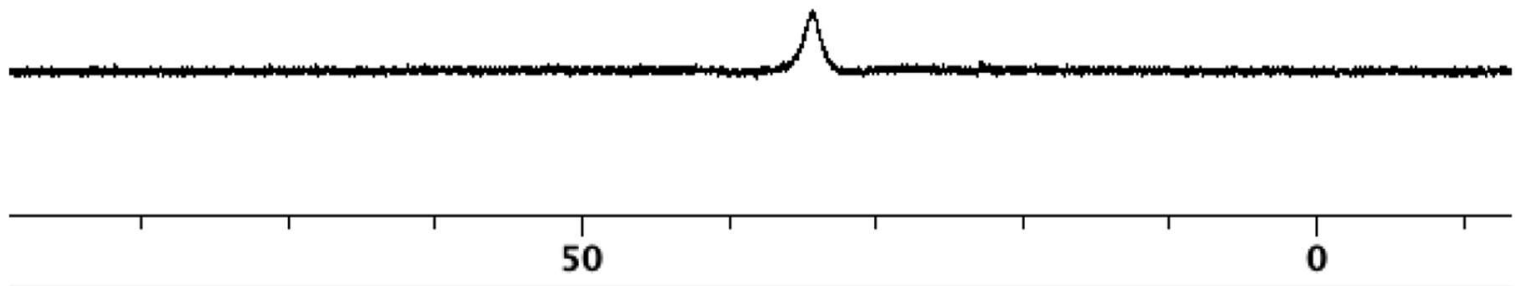
Figure S7. ${ }^{1} \mathrm{H}$ NMR spectrum of $2 \mathrm{c}\left(600 \mathrm{~Hz}, \mathrm{CDCl}_{3}\right)$. Stars denote residual $\mathrm{CHCl}_{3}$ solvent.

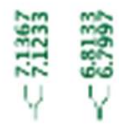
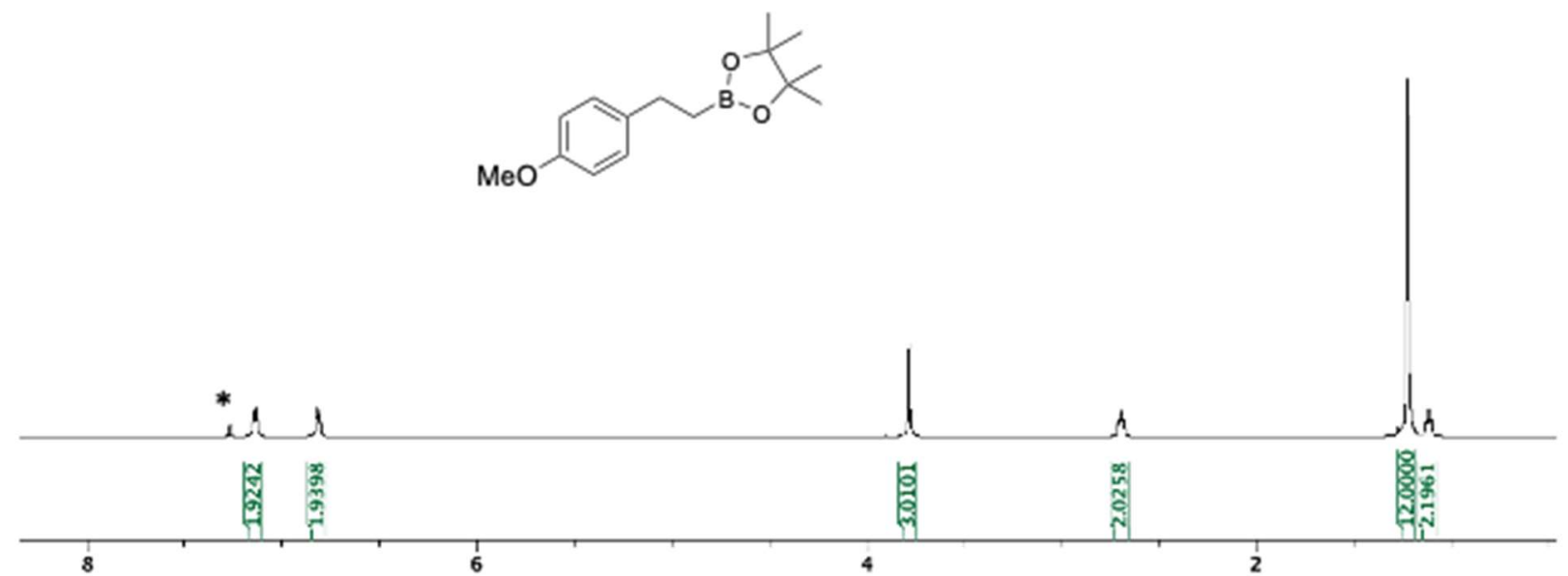

Figure S8. ${ }^{13} \mathrm{C}\left\{{ }^{1} \mathrm{H}\right\}$ NMR spectrum of $2 \mathbf{c}(150.8 \mathrm{~Hz}, \mathrm{CDCl} 3)$. Stars denote residual $\mathrm{CDCl}_{3}$ solvent.
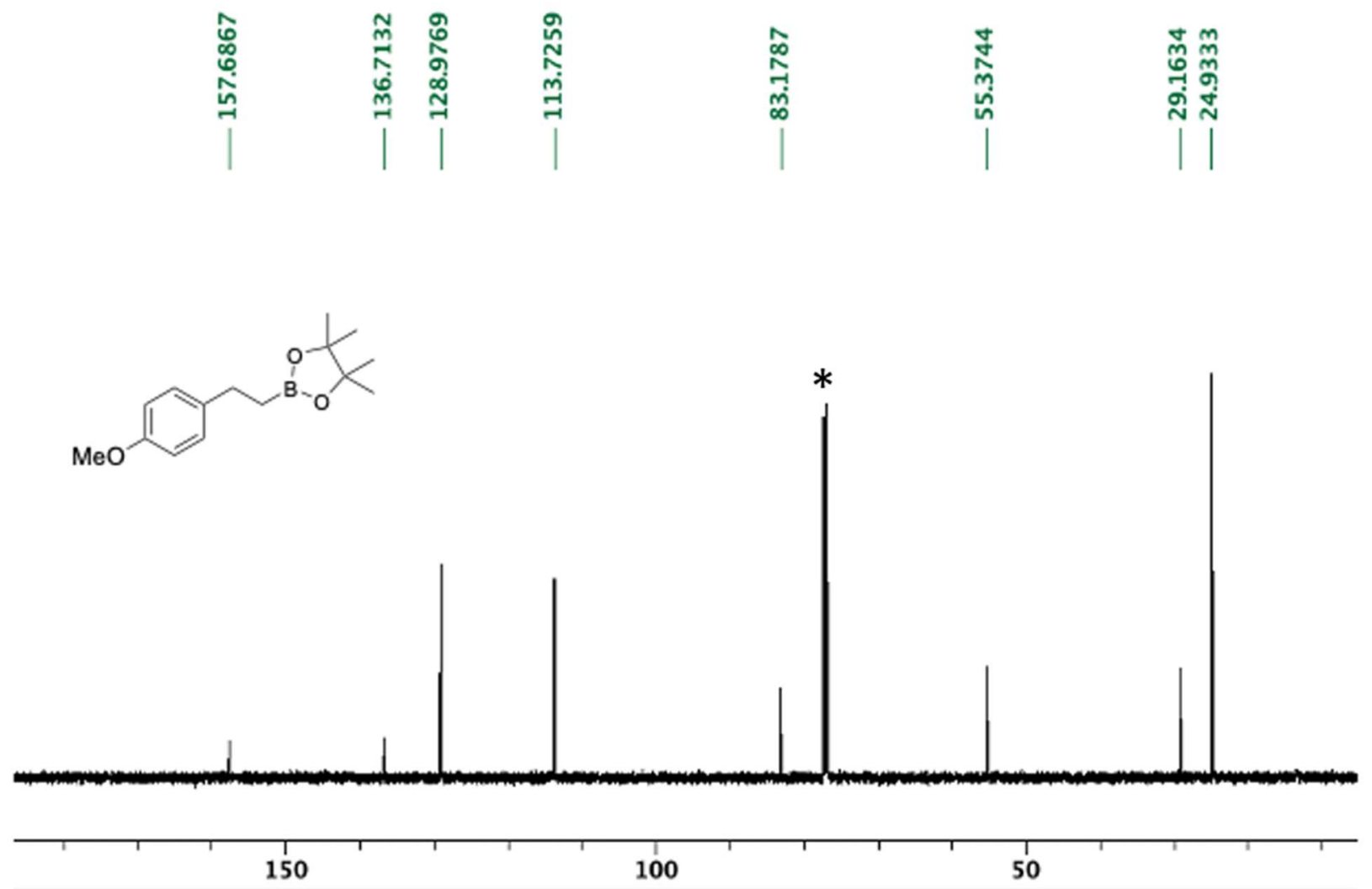
Figure S9. ${ }^{11} \mathrm{~B}$ NMR spectrum of $2 \mathrm{c}\left(192.5 \mathrm{~Hz}, \mathrm{CDCl}_{3}\right)$.
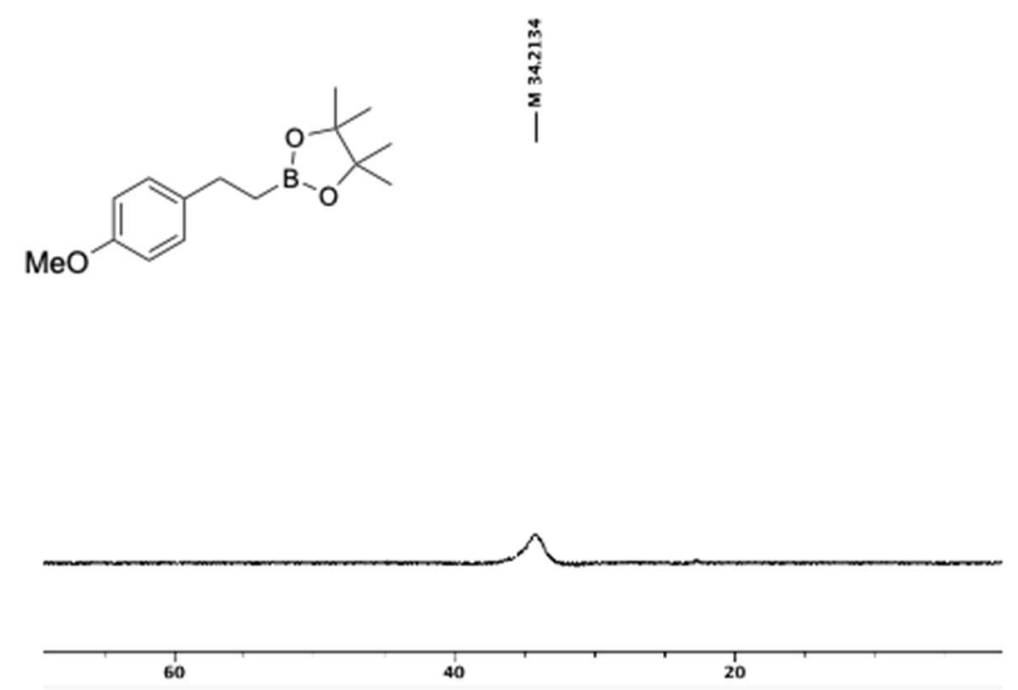

Figure S10. ${ }^{1} \mathrm{H}$ NMR spectrum of $2 \mathbf{d}\left(400 \mathrm{~Hz}, \mathrm{CDCl}_{3}\right)$. Stars denote residual $\mathrm{CHCl}_{3}$ solvent.

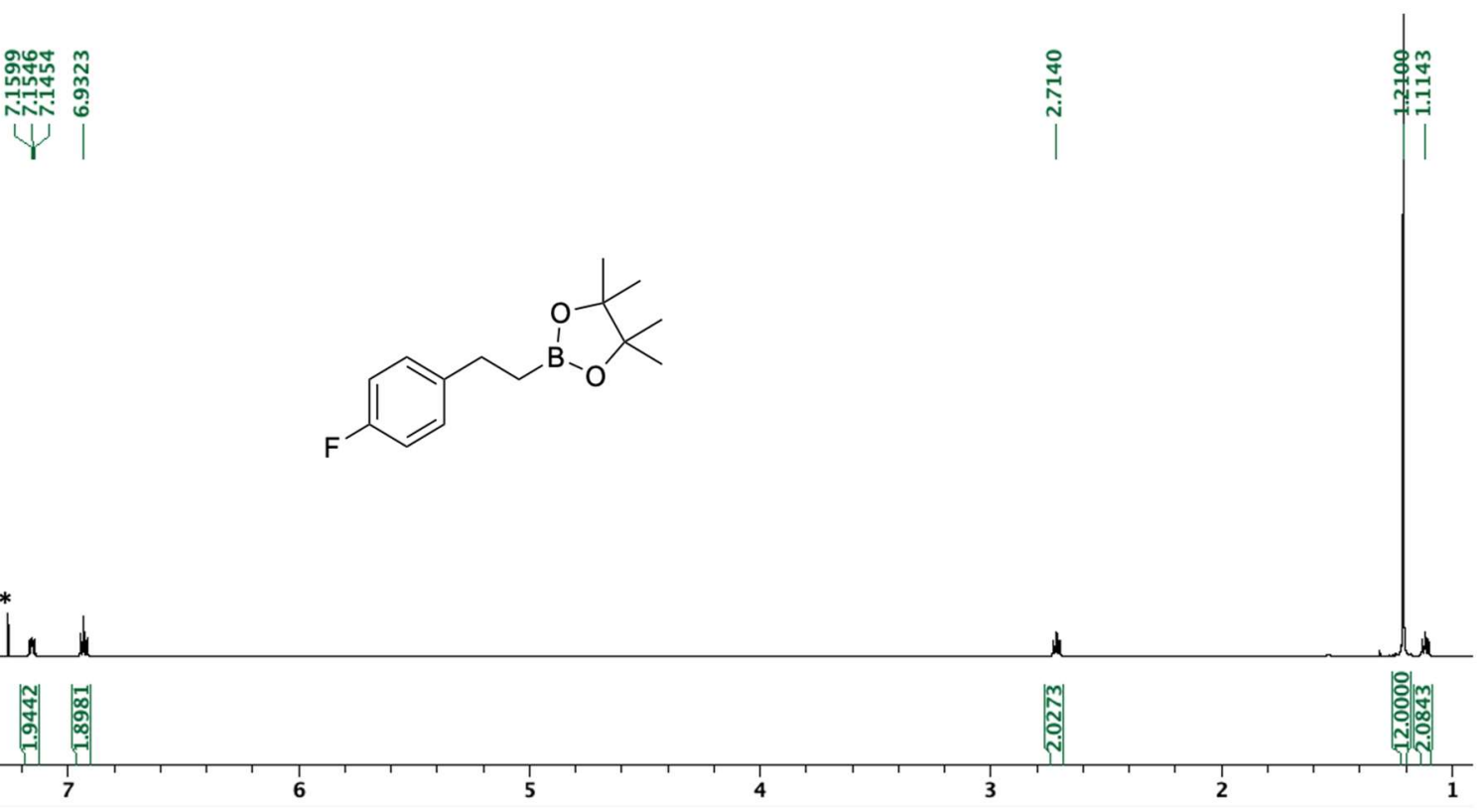


Figure $\mathbf{S 1 1 .}{ }^{13} \mathrm{C}\left\{{ }^{1} \mathrm{H}\right\}$ NMR spectrum of $\mathbf{2 d}\left(150.8 \mathrm{~Hz}, \mathrm{CDCl}_{3}\right)$. Stars denote residual $\mathrm{CDCl}_{3}$ solvent.

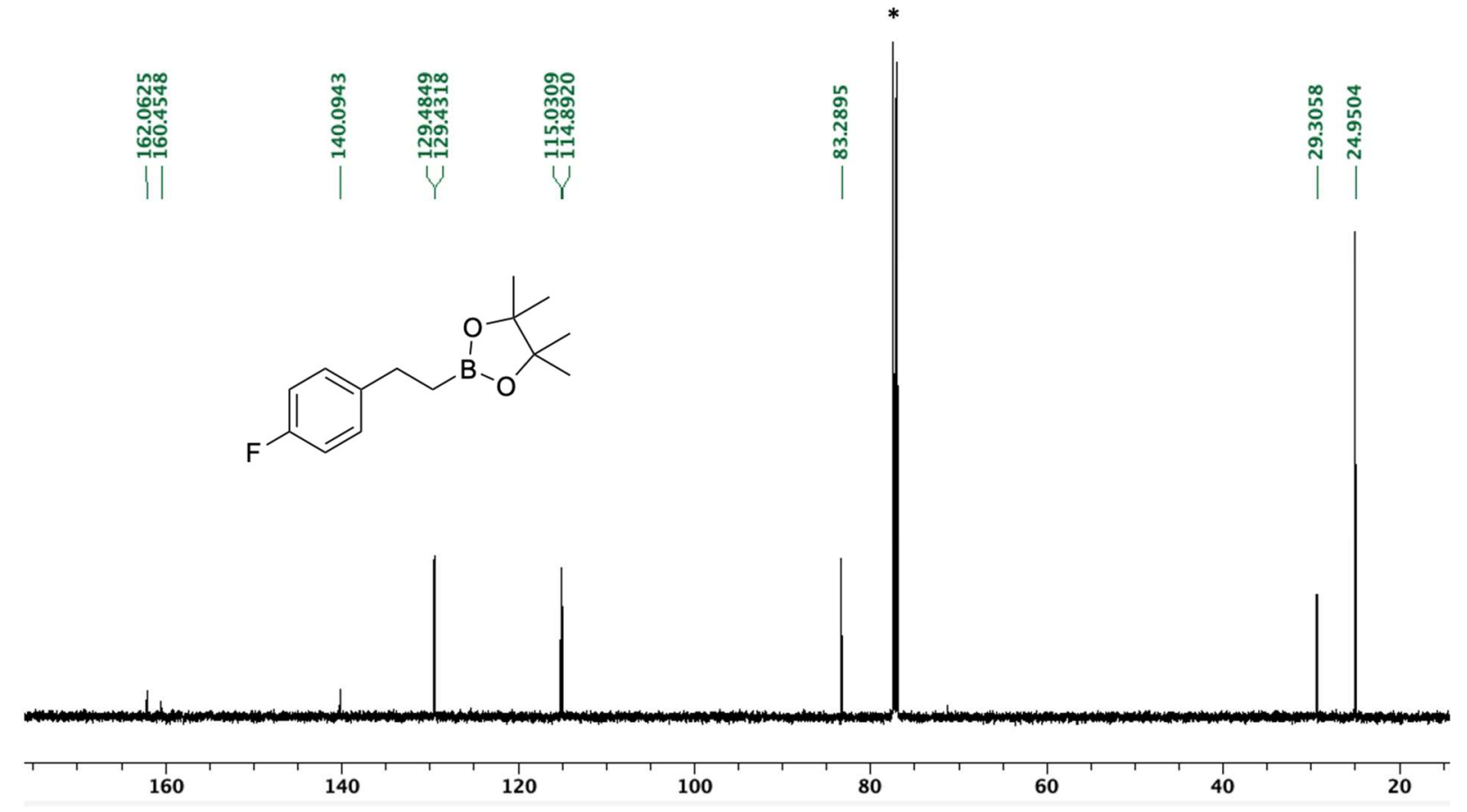

Figure S12. ${ }^{19} \mathrm{~F}\left\{{ }^{1} \mathrm{H}\right\} \mathrm{NMR}$ spectrum of $\mathbf{2} \mathbf{d}\left(470.6 \mathrm{~Hz}, \mathrm{CDCl}_{3}\right)$.<smiles>CC1(C)OB(CCc2ccc(F)cc2)OC1(C)C</smiles>

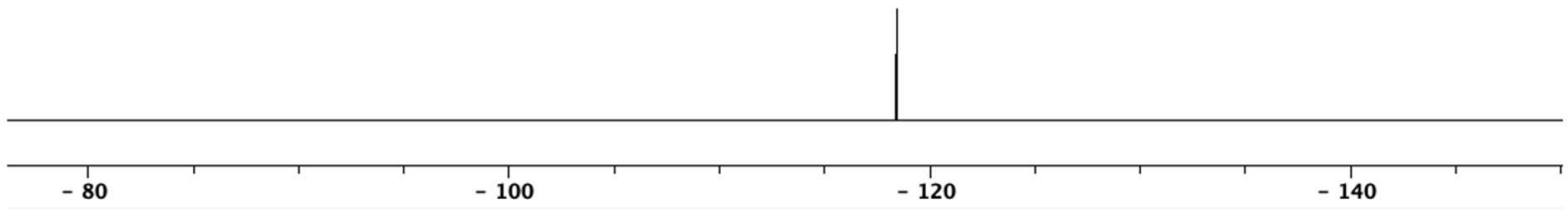


Figure S13. ${ }^{11} \mathrm{~B}$ NMR spectrum of $\mathbf{2 d}\left(192.5 \mathrm{~Hz}, \mathrm{CDCl}_{3}\right)$.<smiles>CC1(C)OB(CCc2ccc(F)cc2)OC1(C)C</smiles><smiles>C1COCN1</smiles>
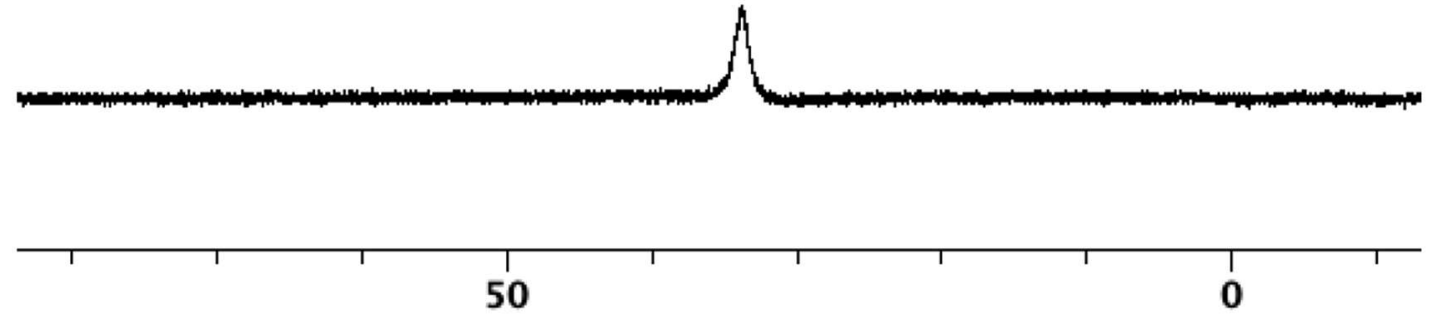

Figure S14. ${ }^{1} \mathrm{H}$ NMR spectrum of crude catalytic reaction mixture to form $2 \mathbf{e}(400 \mathrm{~Hz}$, $\mathrm{CDCl}_{3}$ ) with hexamethylbenzene added as an internal standard. Stars denote residual THF solvent and hexamethylbenzene.

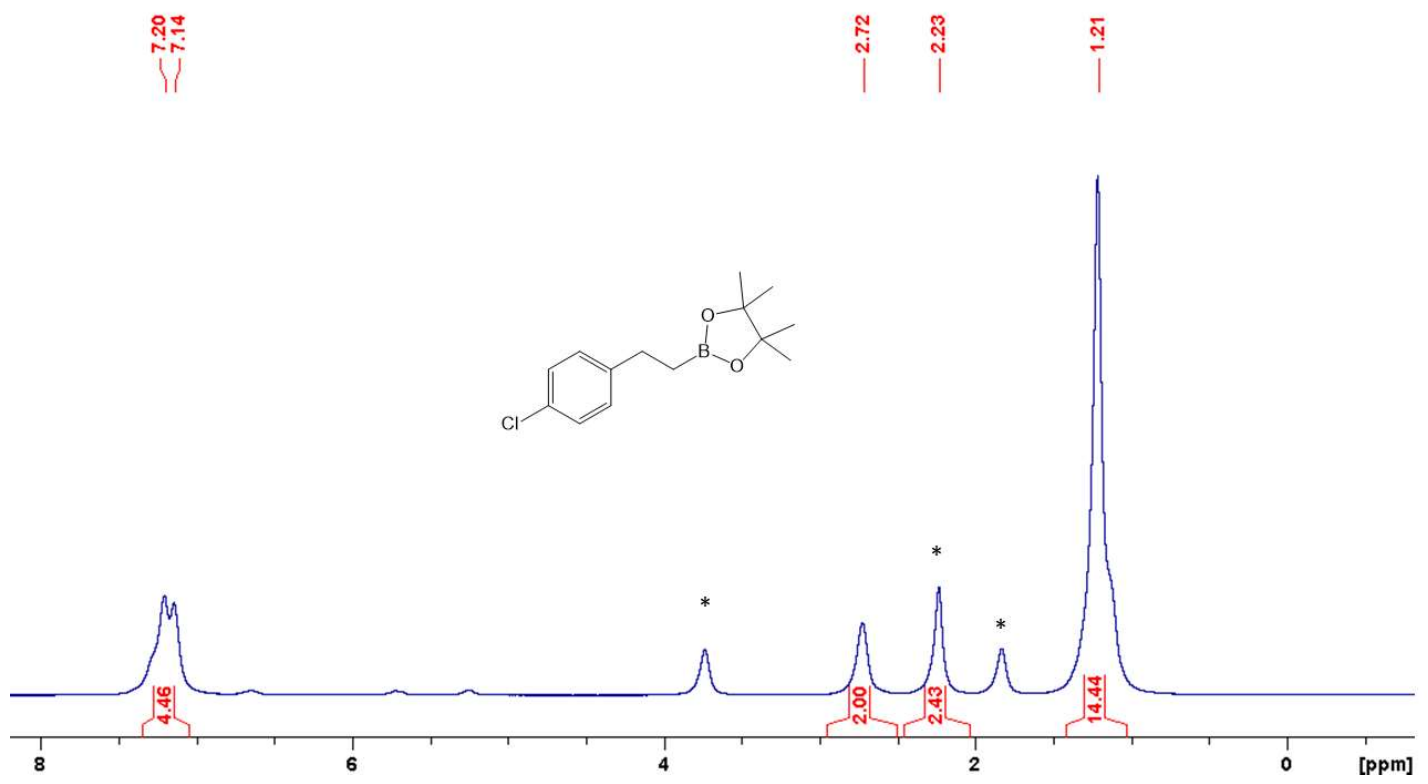


Figure S15. ${ }^{1} \mathrm{H}$ NMR spectrum of crude catalytic reaction mixture to form $2 \mathrm{ff}(400 \mathrm{~Hz}$, $\mathrm{CDCl}_{3}$ ). Stars denote 4-bromostyrene and hexamethylbenzene. Product $\mathbf{2 f}$ is denoted with \#.

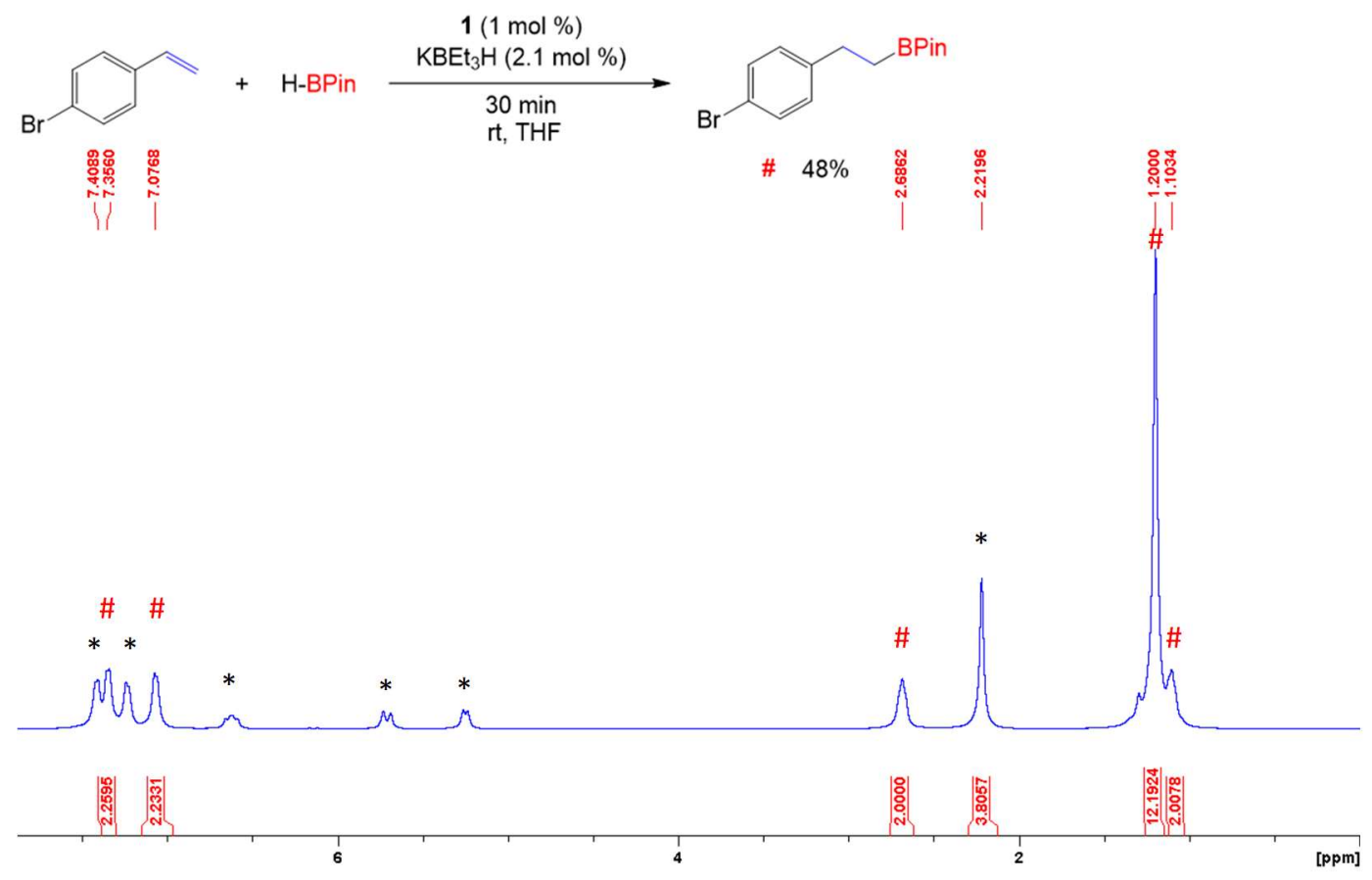

Figure S16. ${ }^{1} \mathrm{H}$ NMR spectrum of $\mathbf{2 g}\left(400 \mathrm{~Hz}, \mathrm{CDCl}_{3}\right)$. Stars denote residual $\mathrm{CHCl}_{3}$ solvent.

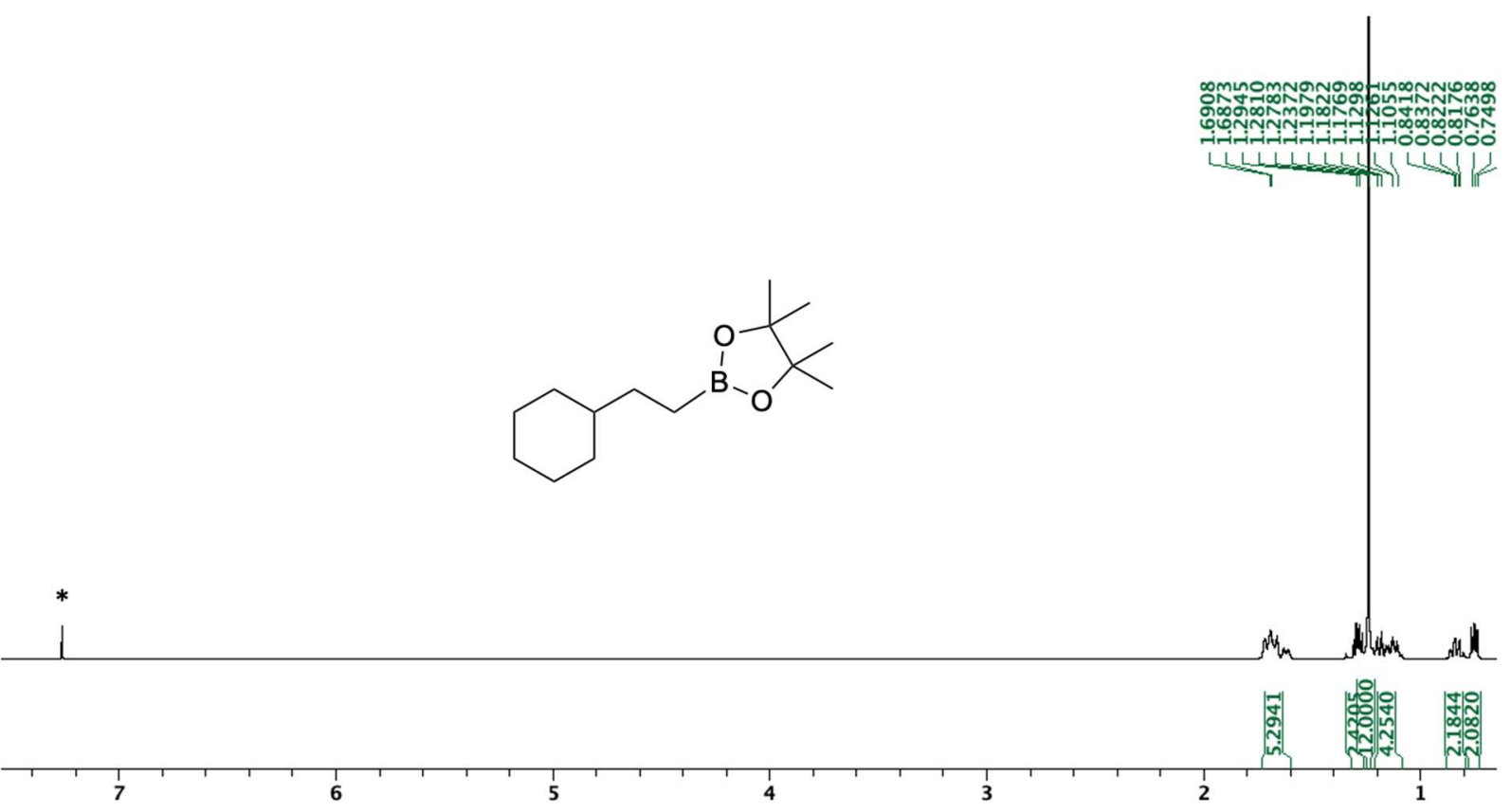


Figure S17. ${ }^{13} \mathrm{C}\left\{{ }^{1} \mathrm{H}\right\}$ NMR spectrum of $\mathbf{2} \mathbf{g}\left(150.8 \mathrm{~Hz}, \mathrm{CDCl}_{3}\right)$. Stars denote residual $\mathrm{CDCl}_{3}$ solvent.

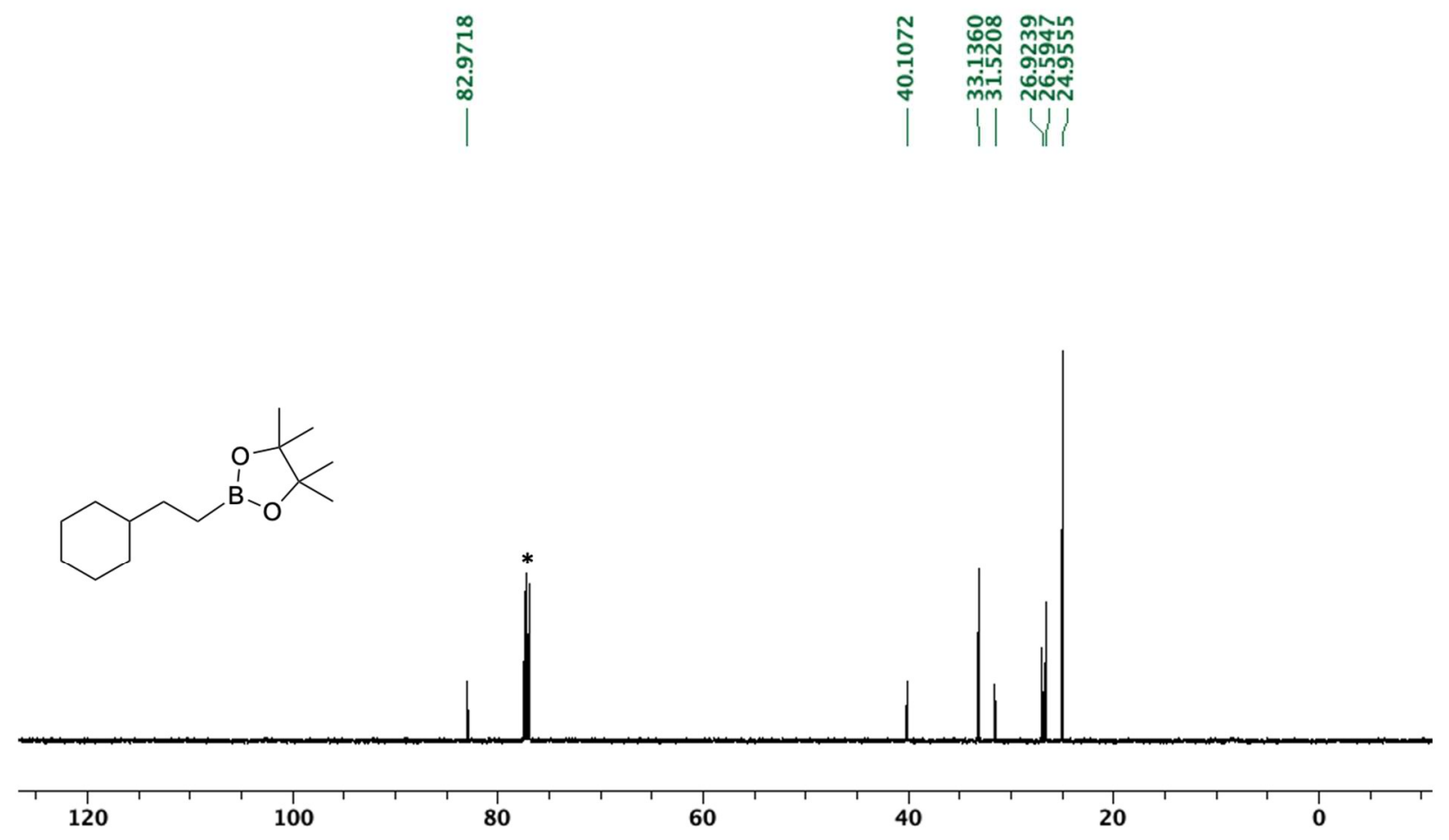

Figure S18. ${ }^{11} \mathrm{~B}$ NMR spectrum of $\mathbf{2 g}\left(192.5 \mathrm{~Hz}, \mathrm{CDCl}_{3}\right)$.
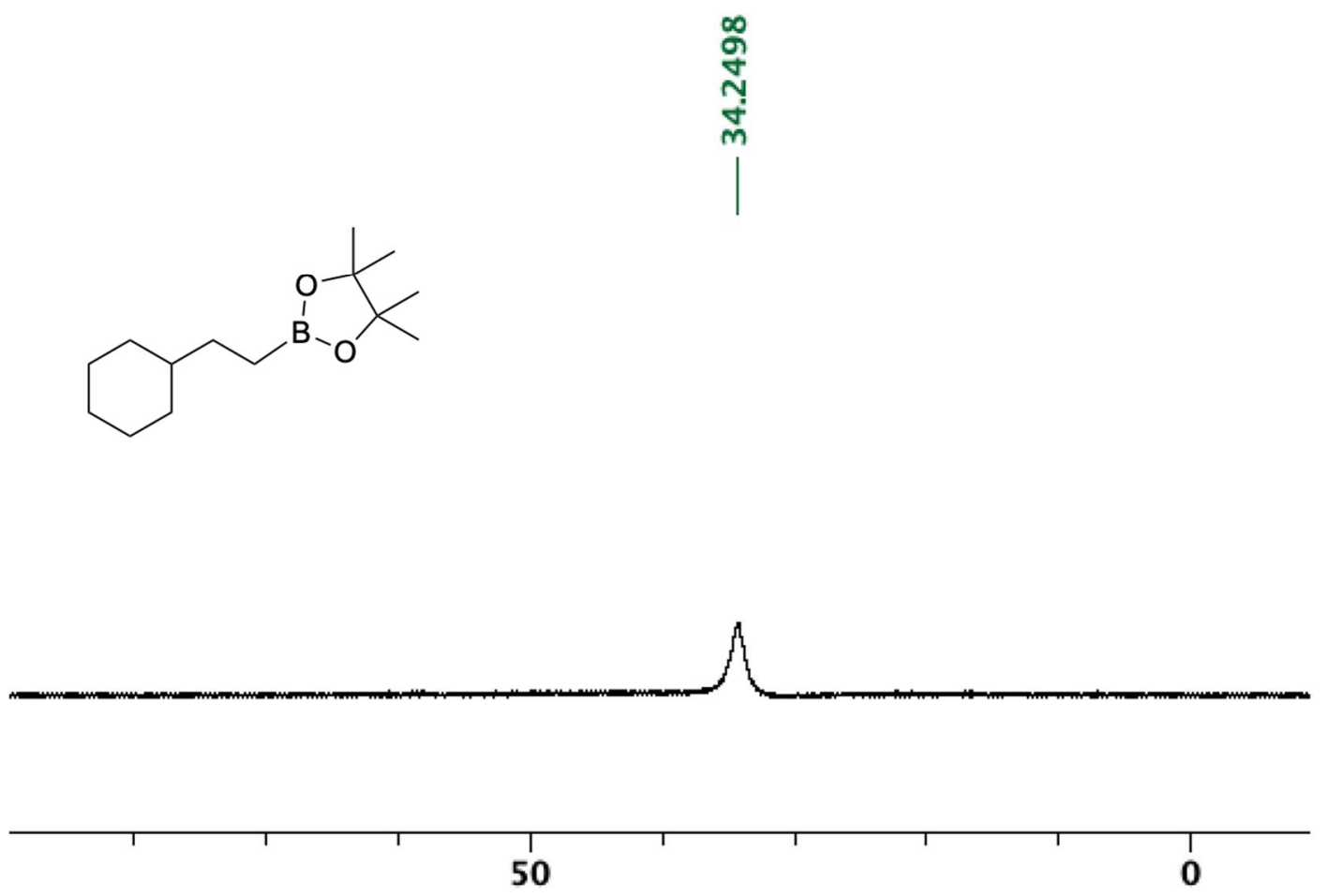
Figure S19. ${ }^{1} \mathrm{H}$ NMR spectrum of $2 \mathbf{h}\left(600 \mathrm{~Hz}, \mathrm{CDCl}_{3}\right)$. Stars denote residual $\mathrm{CHCl}_{3}$ solvent.

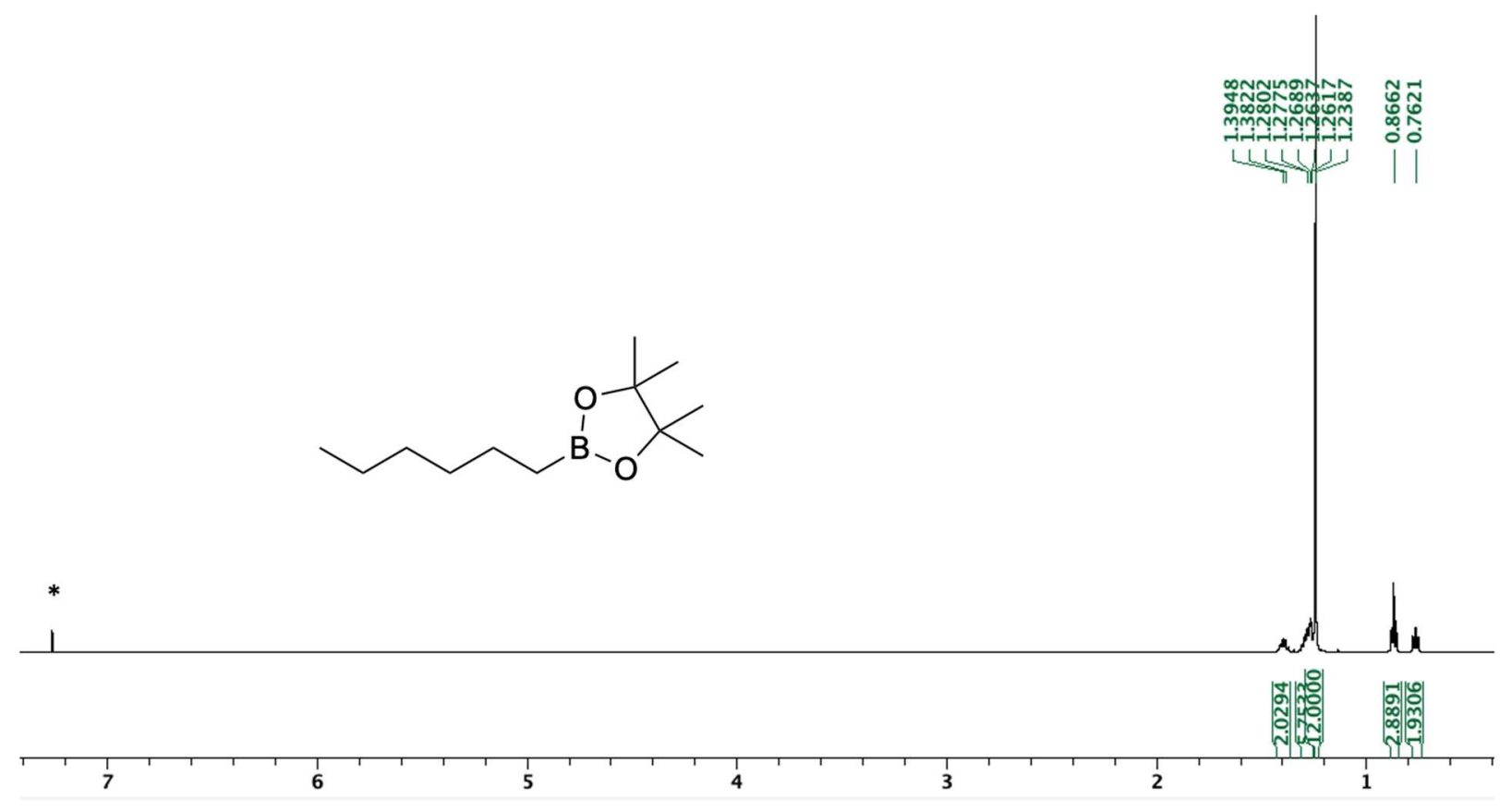

Figure S20. ${ }^{13} \mathrm{C}\left\{{ }^{1} \mathrm{H}\right\}$ NMR spectrum of $\mathbf{2} \mathbf{h}\left(150.8 \mathrm{~Hz}, \mathrm{CDCl}_{3}\right)$. Stars denote residual $\mathrm{CDCl}_{3}$ solvent.
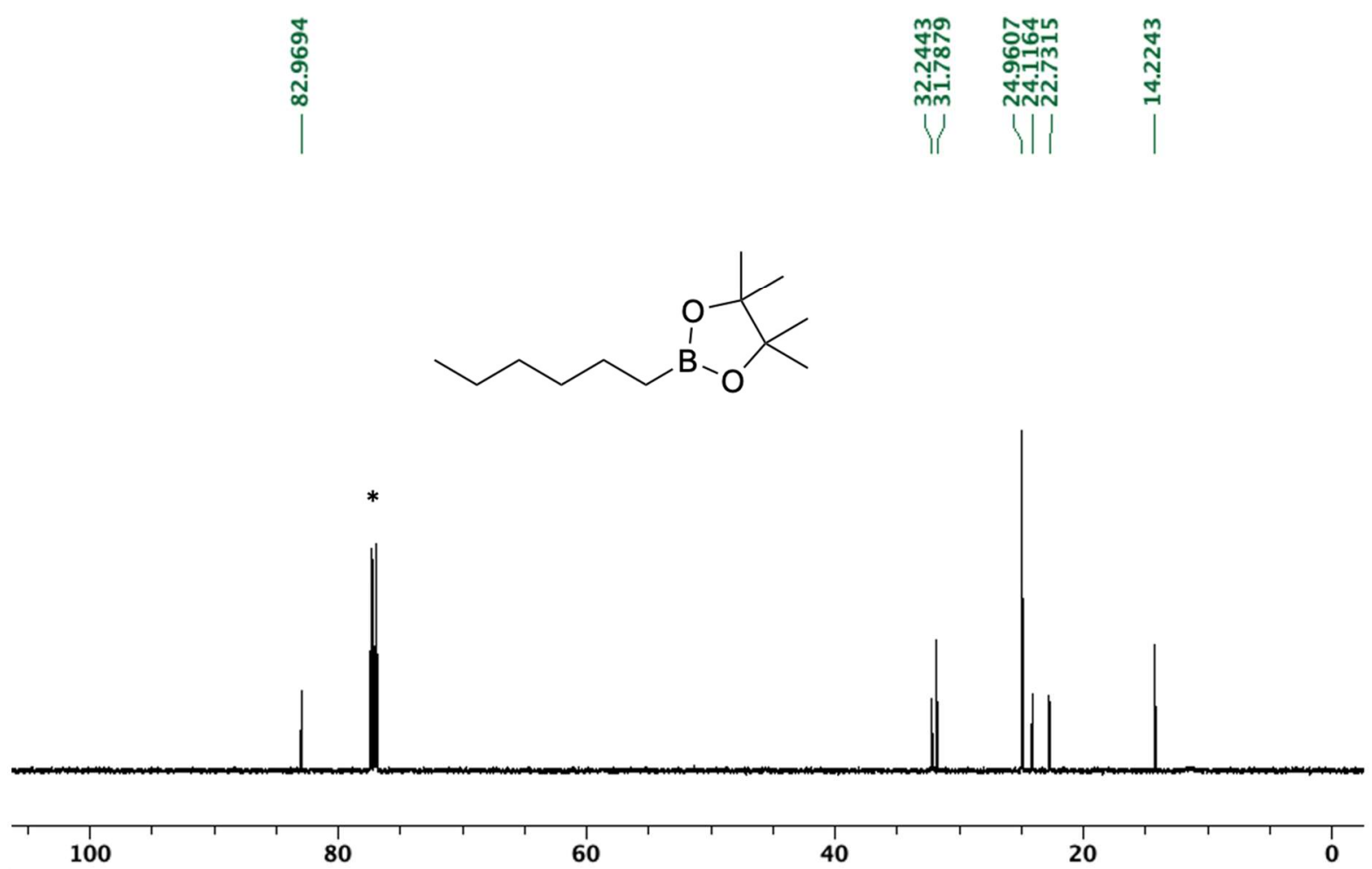
Figure S21. ${ }^{11} \mathrm{~B}$ NMR spectrum of $\mathbf{2 h}\left(192.5 \mathrm{~Hz}, \mathrm{CDCl}_{3}\right)$.

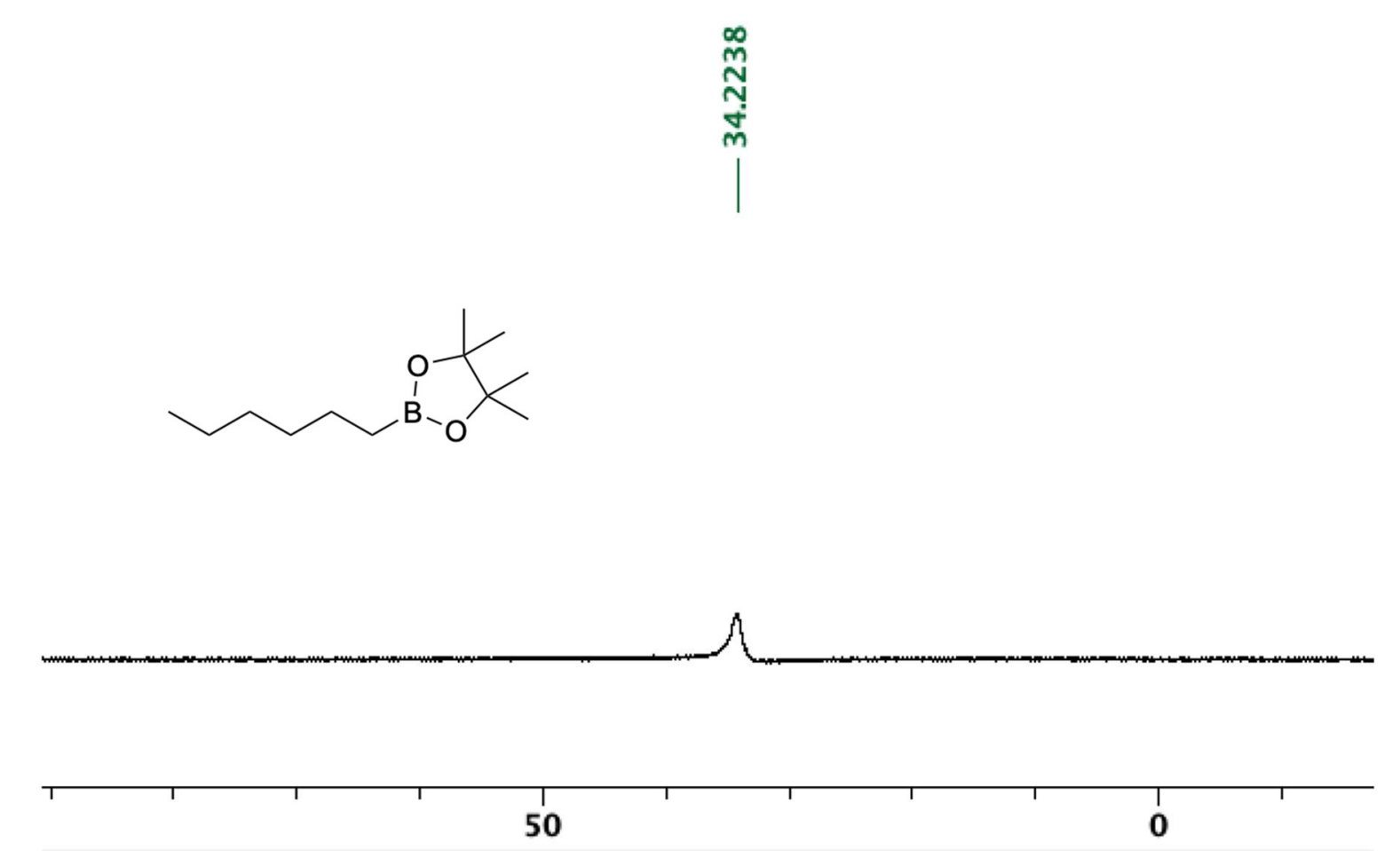

Figure S22. ${ }^{1} \mathrm{H}$ NMR spectrum of $2 \mathbf{i}\left(400 \mathrm{~Hz}, \mathrm{CDCl}_{3}\right)$. Stars denote residual $\mathrm{CHCl}_{3}$ solvent.

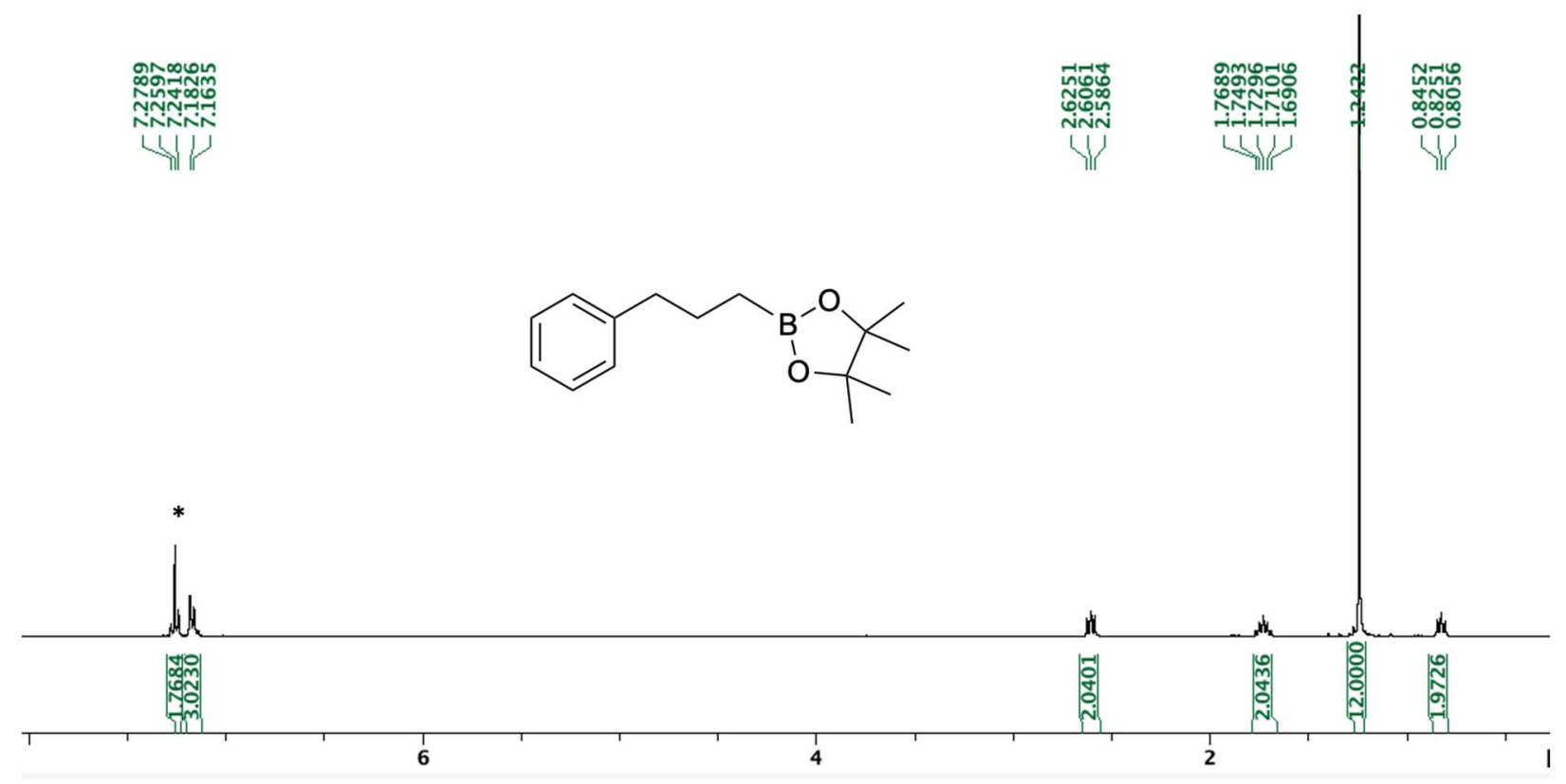


Figure S23. ${ }^{13} \mathrm{C}\left\{{ }^{1} \mathrm{H}\right\}$ NMR spectrum of $2 \mathbf{i}\left(150.8 \mathrm{~Hz}, \mathrm{CDCl}_{3}\right)$. Stars denote residual $\mathrm{CDCl}_{3}$ solvent.

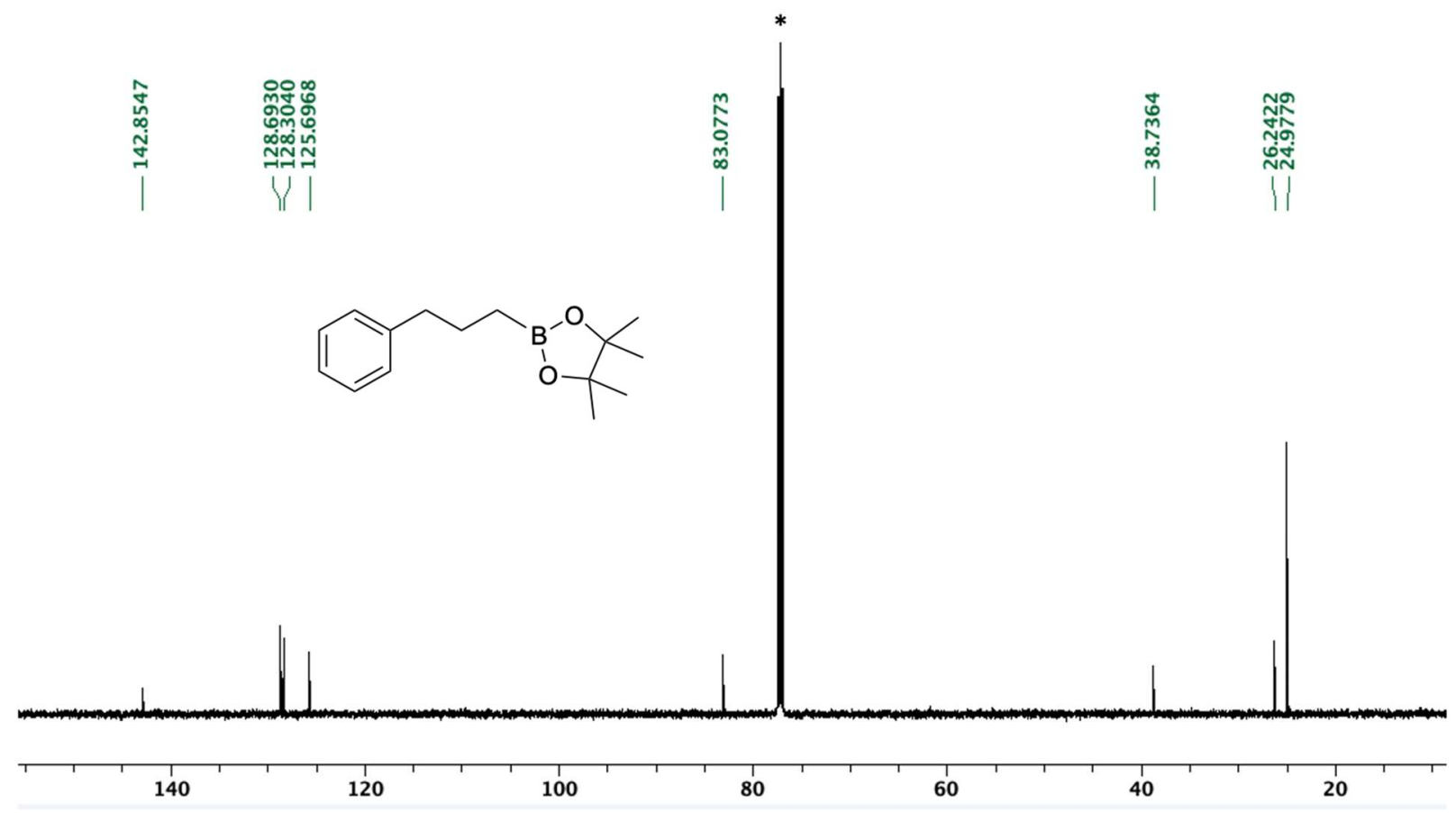

Figure S24. ${ }^{11} \mathrm{~B}$ NMR spectrum of $2 \mathbf{i}\left(192.5 \mathrm{~Hz}, \mathrm{CDCl}_{3}\right)$.
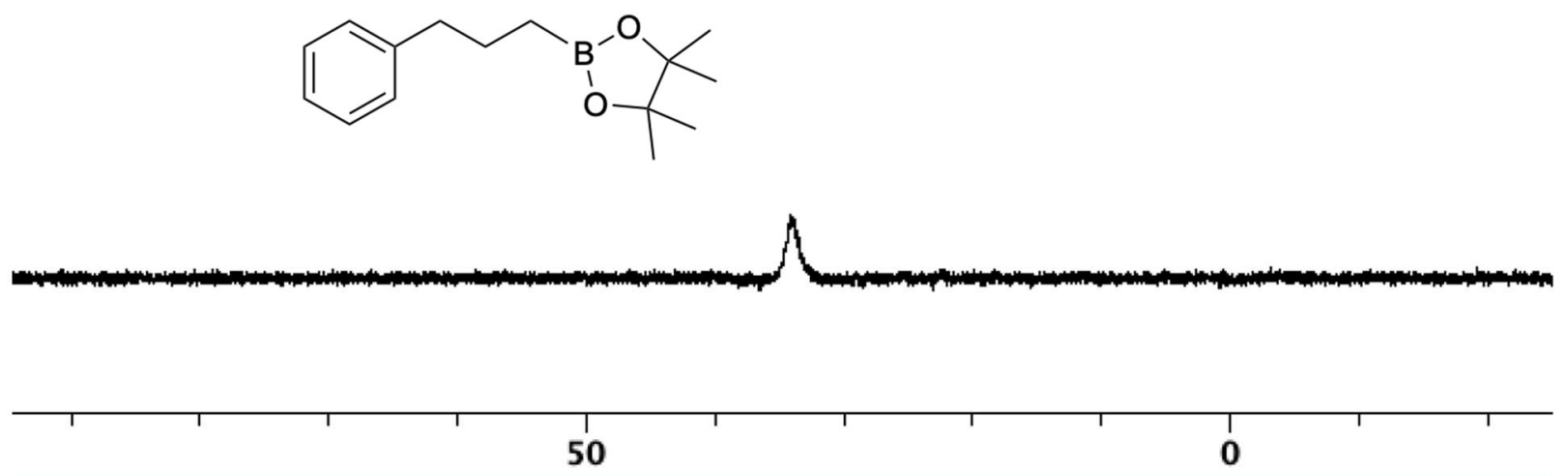
Figure S25. ${ }^{1} \mathrm{H}$ NMR spectrum of $2 \mathrm{j}\left(400 \mathrm{~Hz}, \mathrm{CDCl}_{3}\right)$. Stars denote residual $\mathrm{CHCl}_{3}$ solvent.

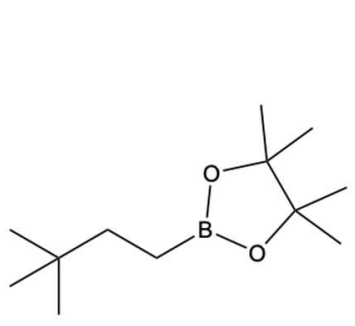

\section{*}

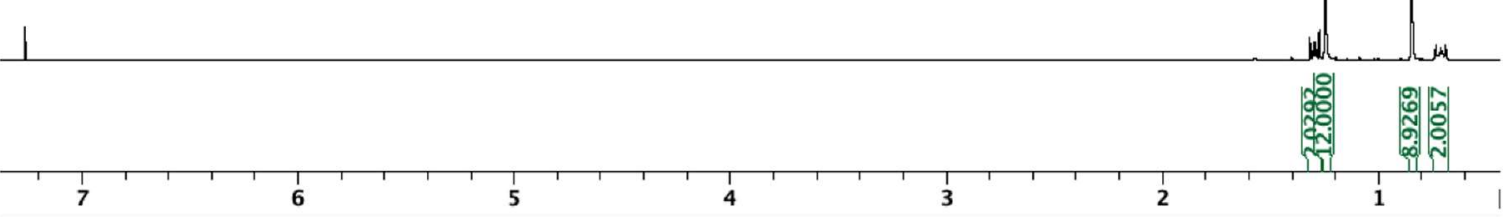

Figure S26. ${ }^{13} \mathrm{C}\left\{{ }^{1} \mathrm{H}\right\}$ NMR spectrum of $2 \mathbf{j}\left(100.6 \mathrm{~Hz}, \mathrm{CDCl}_{3}\right)$. Stars denote residual $\mathrm{CDCl}_{3}$ solvent.

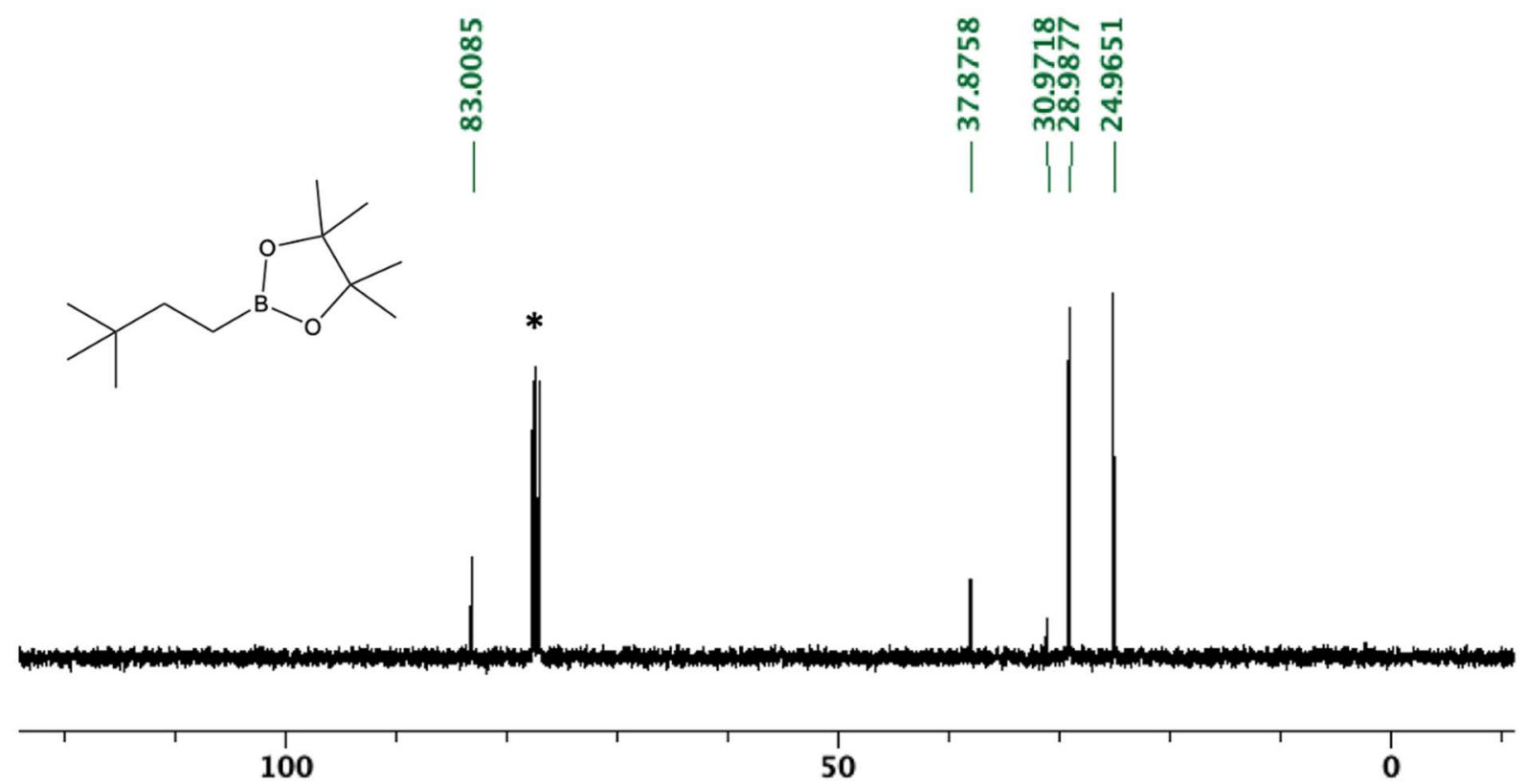


Figure S27. ${ }^{11} \mathrm{~B}$ NMR spectrum of $\mathbf{2 j}\left(192.5 \mathrm{~Hz}, \mathrm{CDCl}_{3}\right)$.

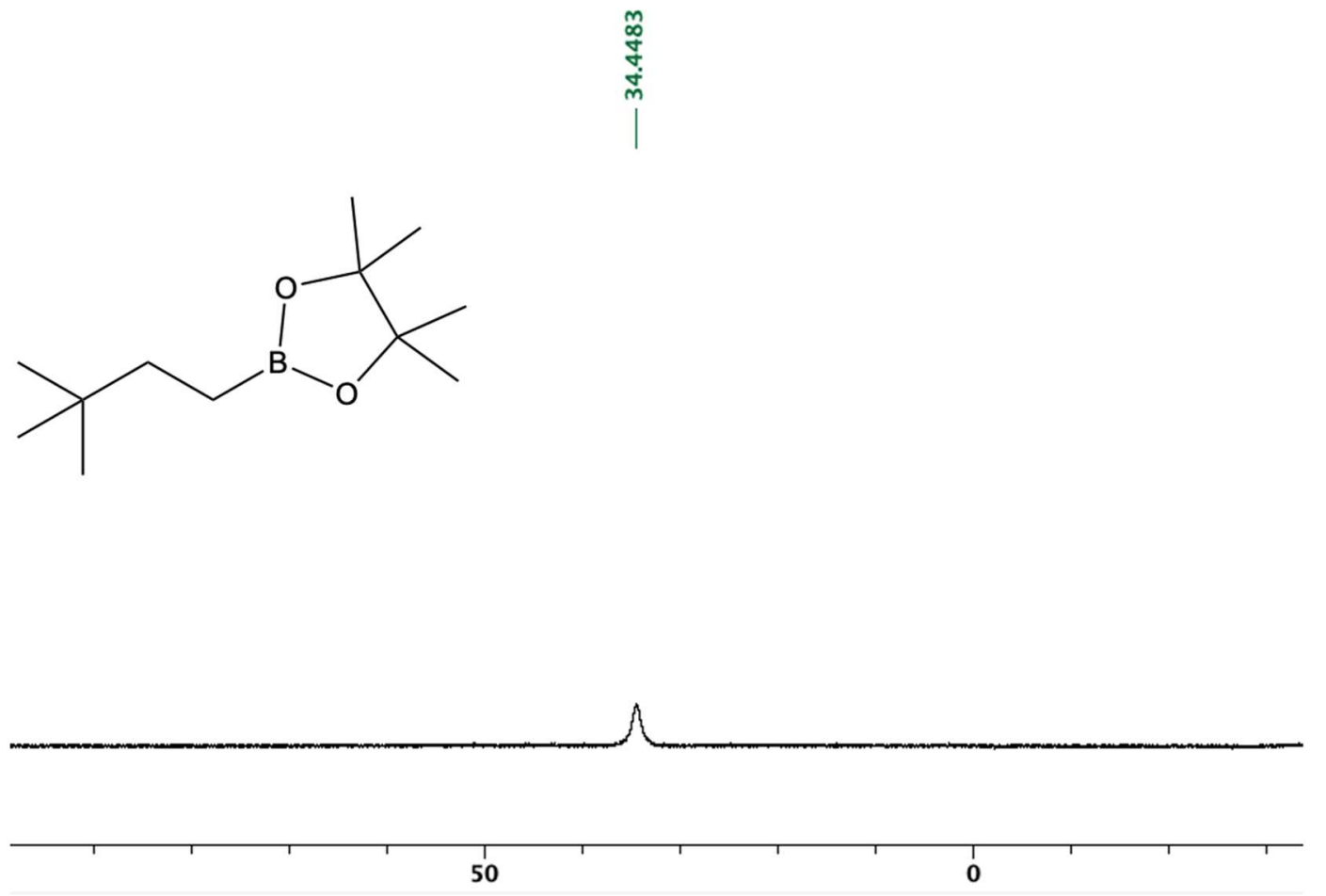

Figure S28. ${ }^{1} \mathrm{H}$ NMR spectrum of crude catalytic reaction mixture to form $\mathbf{2 k}(400 \mathrm{~Hz}$, $\mathrm{CDCl}_{3}$ ). Stars denote residual $\mathrm{CHCl}_{3}$ solvent, allyl phenyl ether, hexamethylbenzene. Product $\mathbf{2 k}$ is denoted with \#.

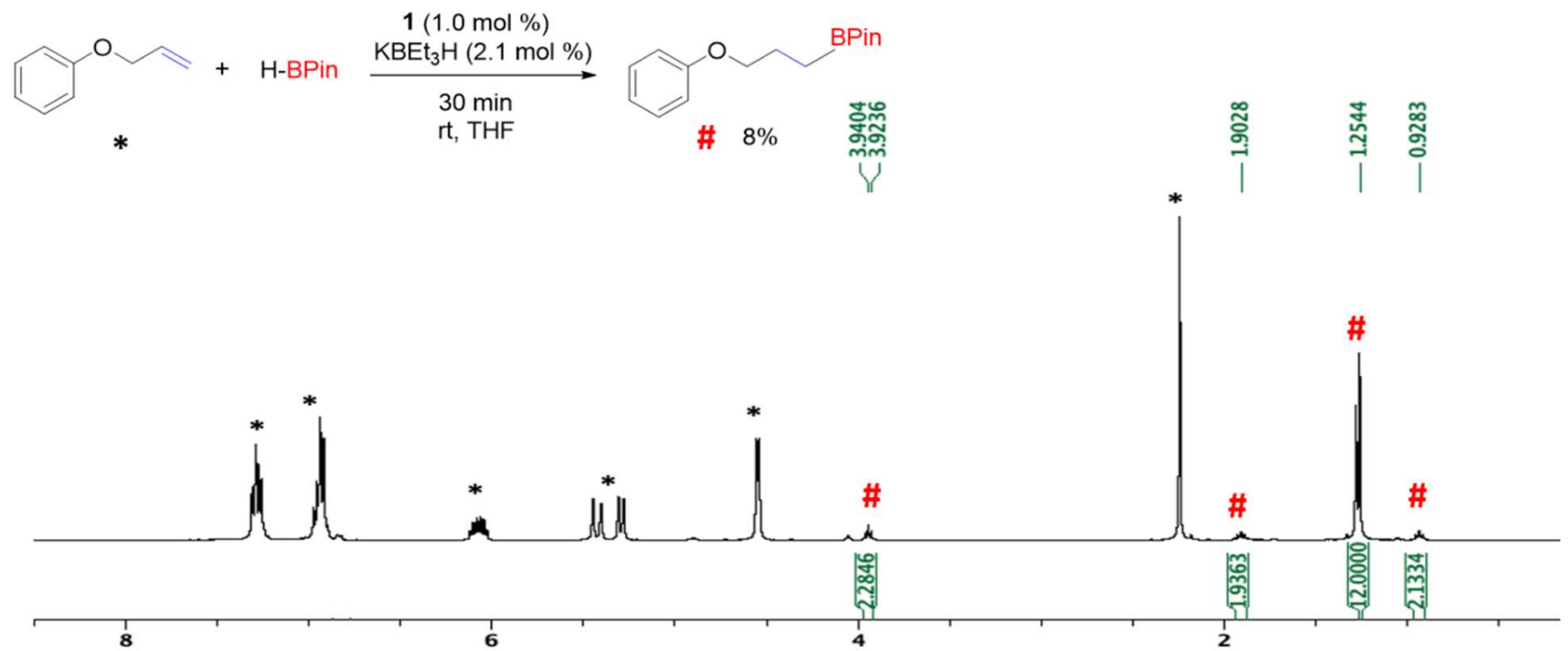


Figure S29. ${ }^{1} \mathrm{H}$ NMR spectrum of $2 \mathrm{I}$ generated under standard catalytic conditions using a 1:1 ratio of HBPin to 5 -hexen-2-one $\left(400 \mathrm{~Hz}, \mathrm{C}_{6} \mathrm{D}_{6}\right)$. Stars denote residual $\mathrm{C}_{6} \mathrm{D}_{5} \mathrm{H}$ solvent.
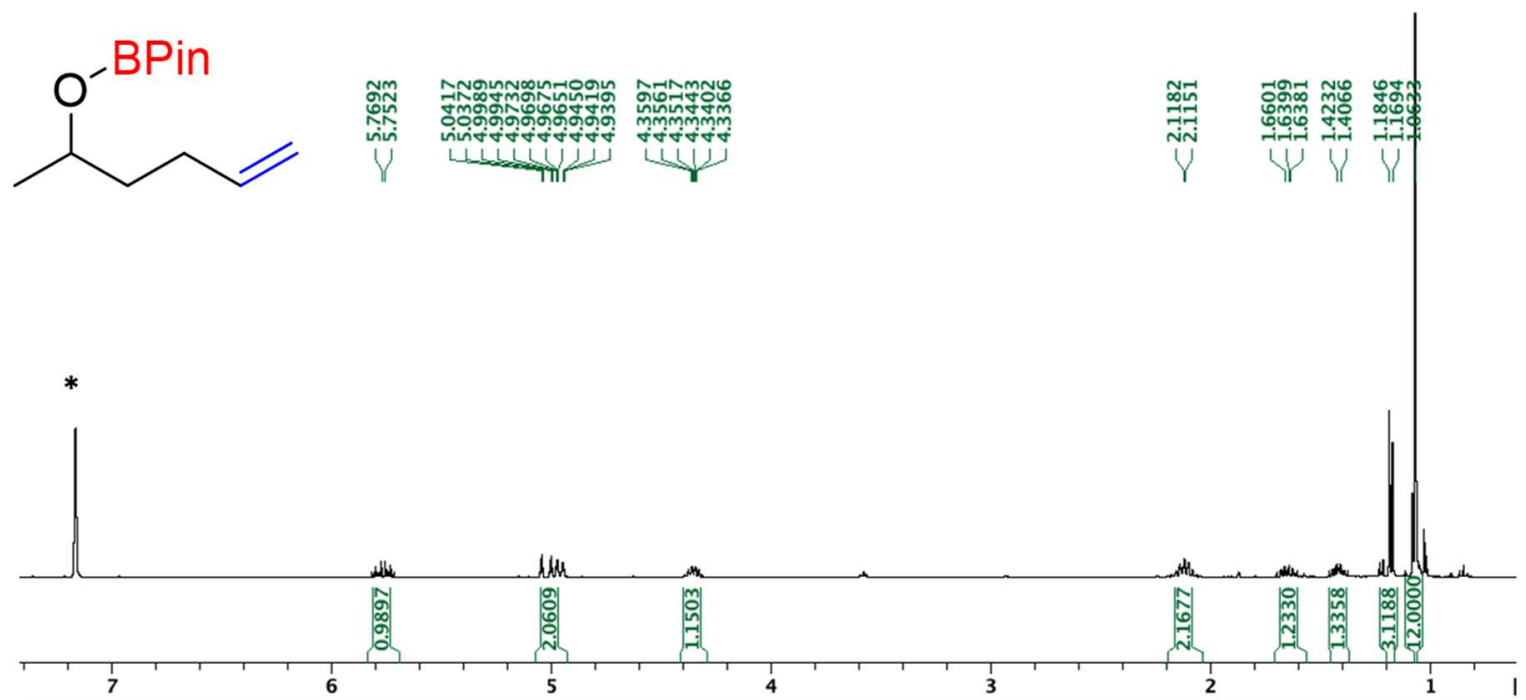

Figure S30. ${ }^{1} \mathrm{H}$ NMR spectrum of the mixture of $2 \mathrm{I}$ and $2 \mathrm{l}$ ' generated under standard catalytic conditions using a 2:1 ratio of HBPin to 5-hexen-2-one $\left(400 \mathrm{~Hz}, \mathrm{CDCl}_{3}\right)$. Stars denote $\mathbf{2} \mathbf{I}$ and $\mathbf{2} \mathbf{l}$ ' is denoted with \#.
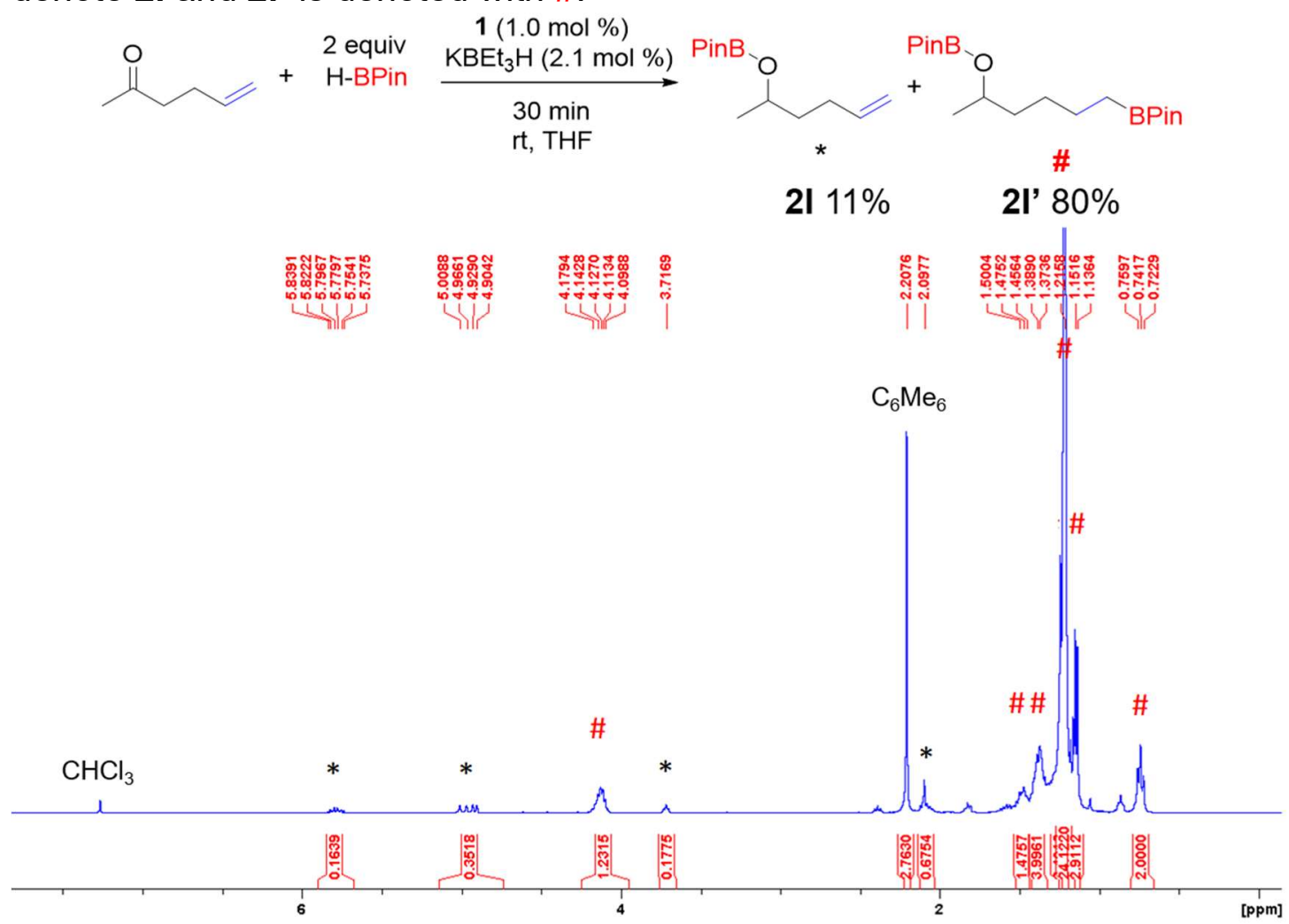
Figure S31. ' $\mathrm{H}$ NMR spectrum of $2 \mathrm{I}^{\prime}\left(400 \mathrm{~Hz}, \mathrm{CDCl}_{3}\right)$. Stars denote hexamethybenzene and residual $\mathrm{CHCl}_{3}$ solvent.

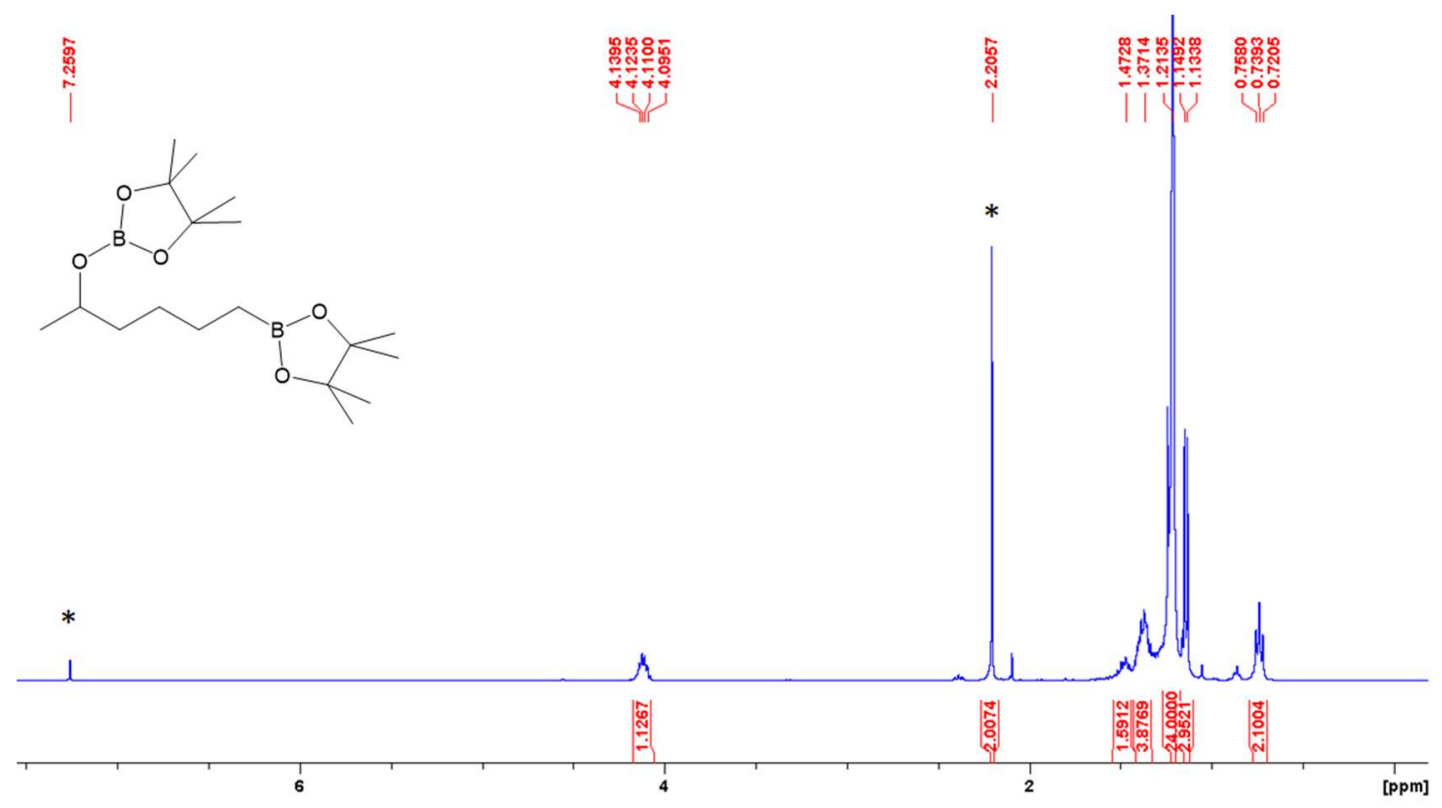

Figure S32. ${ }^{31} \mathrm{P}\left\{{ }^{1} \mathrm{H}\right\}$ NMR spectra of the reaction mixture upon completion of catalysis (bottom, black, THF) and an authentic sample of $\left[(\mathrm{PPP}) \mathrm{CoH}_{2}{ }^{7}\right.$ (top, green, $\mathrm{C}_{6} \mathrm{D}_{6}$ ).

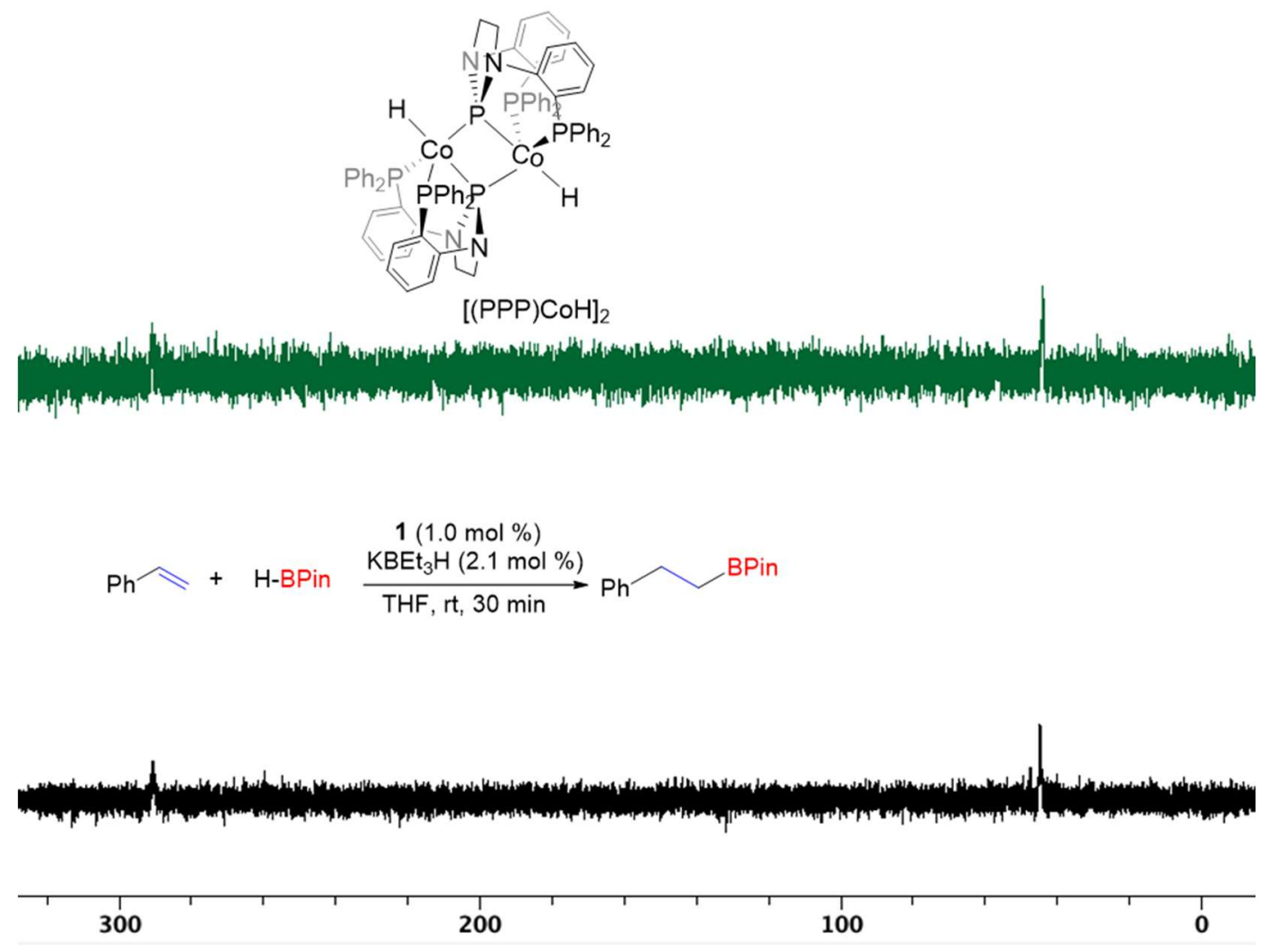


Figure S33. ${ }^{31} \mathrm{P}\left\{{ }^{1} \mathrm{H}\right\}$ NMR spectrum obtained upon addition of $\mathrm{PMe}_{3}$ to the catalytic reaction mixture in the middle of catalysis (top, green, THF) and ${ }^{31} \mathrm{P}\left\{{ }^{1} \mathrm{H}\right\} \mathrm{NMR}$ spectrum an authentic sample of $\left(\mathrm{PP}^{\mathrm{H}} \mathrm{P}\right) \mathrm{Co}(\mathrm{H}) \mathrm{PMe}_{3}{ }^{1}$ (black, bottom, $\left.\mathrm{C}_{6} \mathrm{D}_{6}\right)$. Stars denote a $\mathrm{PMe}_{3}-$ related side product.

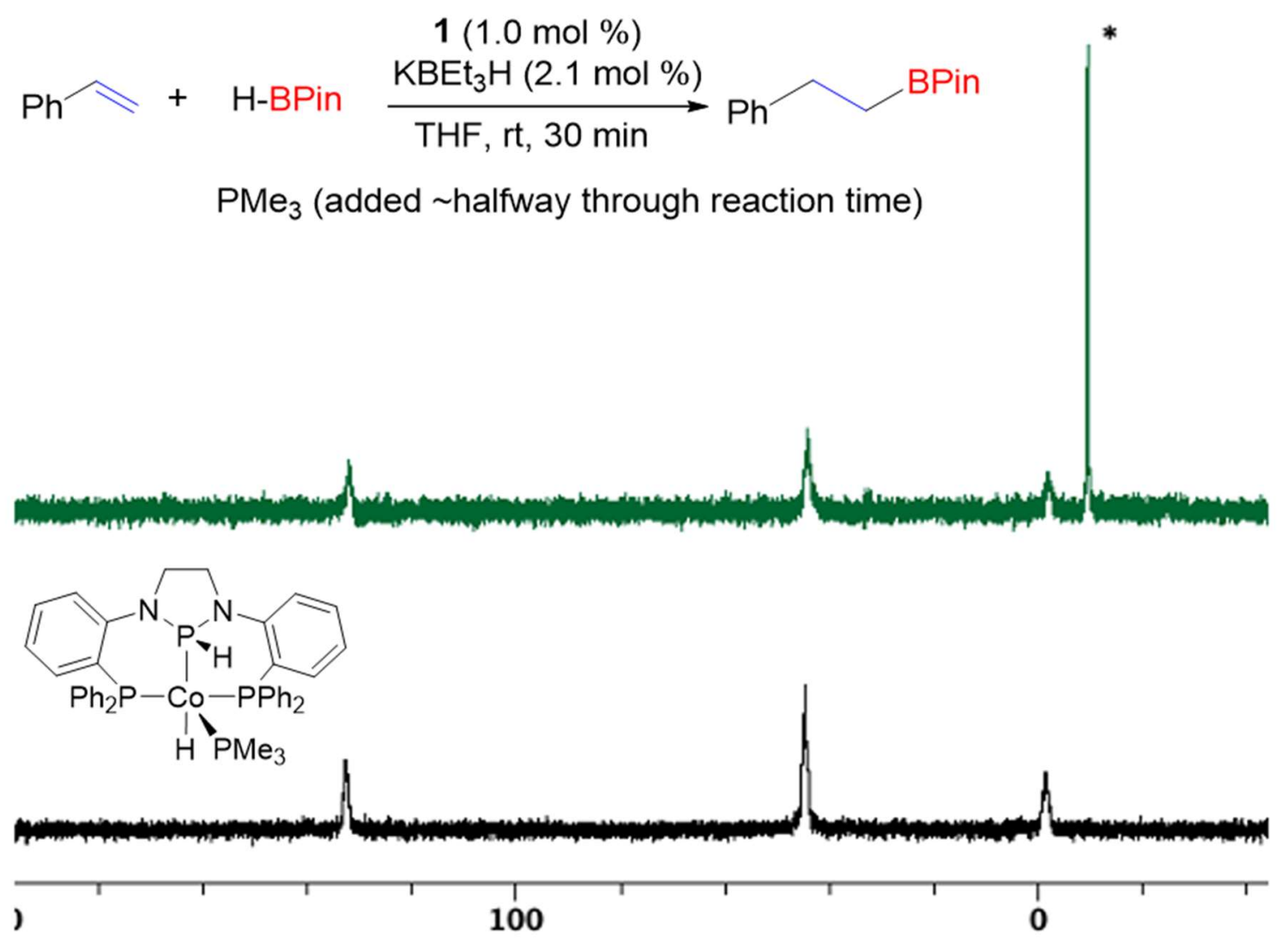

Figure S34. ${ }^{11} \mathrm{~B}$ NMR spectrum obtained upon addition of $20 \mathrm{~mol} \%$ TMEDA to the catalytic reaction mixture to verify that no $\mathrm{BH}_{3} \cdot \operatorname{TMEDA}(26.3 \mathrm{ppm})$ or $\left(\mathrm{BH}_{3}\right)_{2} \cdot \operatorname{TMEDA}(28.4$ ppm) had formed under the reaction conditions. ${ }^{2}$

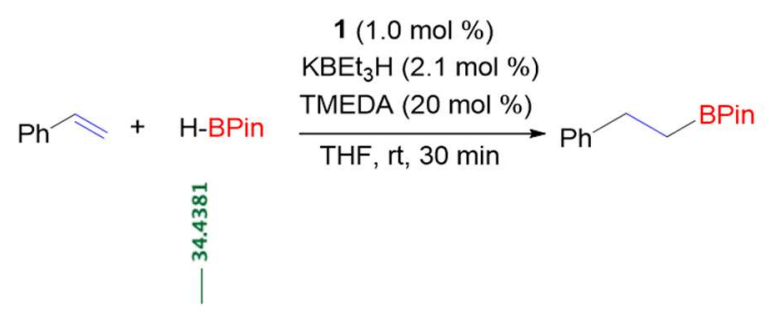

50

o

$-50$ 
Figure S35. ${ }^{2} \mathrm{H}$ NMR spectrum of the product obtained upon styrene hydroboration with DBPin catalyzed by 1 in the presence of $\mathrm{KBEt}_{3} \mathrm{H}$.

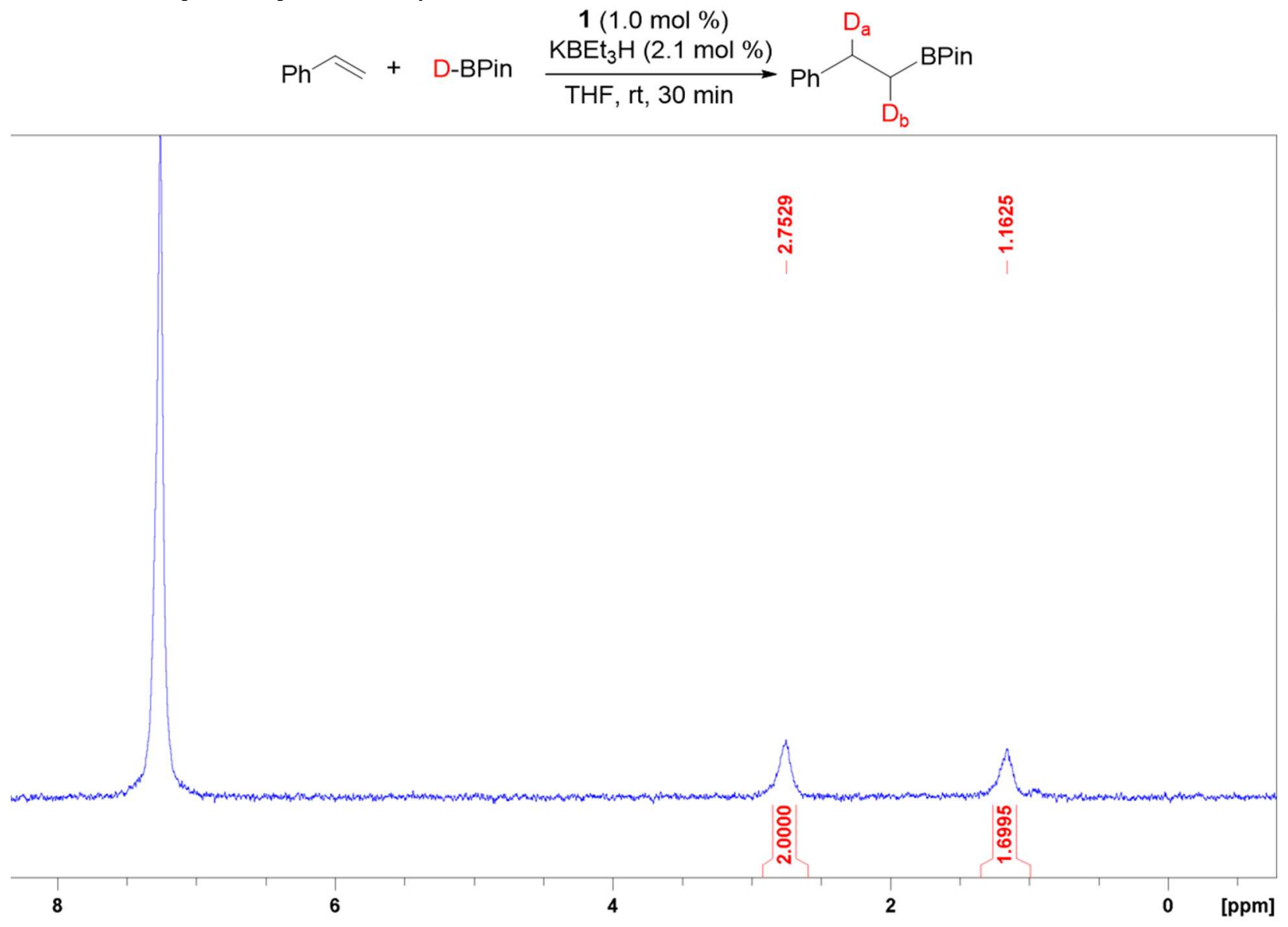




\section{References.}

(1) Poitras, A. M.; Knight, S. E.; Bezpalko, M. W.; Foxman, B. M.; Thomas, C. M. Addition of $\mathrm{H} 2$ Across a Cobalt-Phosphorus Bond. Angew. Chem. Int. Ed. 2018, 57 (6), 1497-1500.

(2) R. Gatti, A.; Wartik, T. Preparation and Properties of the Monoborane Adduct of N,N,N',N'-Tetramethylethylenediamine. Inorg. Chem. 2002, 5 (2), 329-330.

(3) Zhang, L.; Zuo, Z.; Leng, X.; Huang, Z. A Cobalt-Catalyzed Alkene Hydroboration with Pinacolborane. Angew. Chem. Int. Ed. 2014, 53 (10), 2696-2700.

(4) Yi, J.; Liu, J.-H.; Liang, J.; Dai, J.-J.; Yang, C.-T.; Fu, Y.; Liu, L. Alkylboronic Esters from Palladium- and Nickel-Catalyzed Borylation of Primary and Secondary Alkyl Bromides. Adv. Synth. Catal. 2012, 354 (9), 1685-1691.

(5) Zhang, L.; Peng, D.; Leng, X.; Huang, Z. Iron-Catalyzed, Atom-Economical, Chemo- and Regioselective Alkene Hydroboration with Pinacolborane. Angew. Chem. Int. Ed. 2013, 52 (13), 3676-3680.

(6) Arrowsmith, M.; Hadlington, T. J.; Hill, M. S.; Kociok-Köhn, G. MagnesiumCatalysed Hydroboration of Aldehydes and Ketones. Chem. Commun. 2012, 48 (38), 4567-4569.

(7) Poitras, A. M.; Bezpalko, M. W.; Moore, C. E.; Dickie, D. A.; Foxman, B. M.; Thomas, C. M. A Series of Dimeric Cobalt Complexes Bridged by N-Heterocyclic Phosphido Ligands. Inorg. Chem. 2020, 59 (7), 4729-4740. 